\title{
Evolution of Entrepreneurial Judgment with Venture-Specific Experience
}

Ugur Uygur

Loyola University Chicago, uuygur@luc.edu

Sung Min Kim

Loyola University Chicago, skim@luc.edu

Follow this and additional works at: https://ecommons.luc.edu/business_facpubs

Part of the Entrepreneurial and Small Business Operations Commons

Author Manuscript

This is a pre-publication author manuscript of the final, published article.

\section{Recommended Citation}

Uygur, Ugur \& Kim, Sung Min "Evolution of Entrepreneurial Judgment with Venture-Specific Experience," Strategic Entrepreneurship Journal, forthcoming

This Article is brought to you for free and open access by the Faculty Publications and Other Works by Department at Loyola eCommons. It has been accepted for inclusion in School of Business: Faculty Publications and Other Works by an authorized administrator of Loyola eCommons. For more information, please contact ecommons@luc.edu.

\section{cc) $($ ) $९$}

This work is licensed under a Creative Commons Attribution-Noncommercial-No Derivative Works 3.0 License. (c) Strategic Management Society, 2016. 


\title{
Evolution of Entrepreneurial Judgment with Venture-Specific Experience
}

\author{
Ugur Uygur $^{\mathrm{a}}$ \\ Sung Min Kim ${ }^{\mathrm{b}}$ \\ a Loyola University Chicago. 1 E. Pearson, Chicago, IL 60611, USA. \\ 1-312-915-6077; uuygur@luc.edu (Corresponding author) \\ b Loyola University Chicago. 1 E. Pearson, Chicago, IL 60611, USA. \\ 1-312-915-7052; skim@luc.edu \\ * Accepted for publication at Strategic Entrepreneurship Journal
}

\begin{abstract}
This study advances research on entrepreneurial cognition by investigating how entrepreneurial judgment evolves during new venture creation. We conceptualize entrepreneurial judgment as a cognitive process in the minds of entrepreneurs that operates on the causal map i.e., a knowledge structure concerning what factors they believe will help the chances of profitability under uncertainty. At the time of initial epiphany, entrepreneurs construct a cognitive causal map which guides resource allocation decisions. Over time, venture-specific experience accumulates and entrepreneurial judgment evolves in response to their observations. Using a dataset of 524 nascent entrepreneurs, we find that entrepreneurs with more venturespecific experiences have more selective judgments, and have stronger conviction in those judgments. We also find that perceived uncertainty and cognitive dispositions of the individuals affect entrepreneurial judgment.
\end{abstract}

Running Head: Evolution of Entrepreneurial Judgment

Keywords: entrepreneurial judgment; knowledge structure; causal map; experience 


\section{INTRODUCTION}

"The business man himself not merely forms the best estimate he can of the outcome of his actions, but he is likely also to estimate the probability that his estimate is correct...The action which follows upon an opinion depends as much upon the amount of confidence in that opinion as it does upon the favorableness of the opinion itself.” (Knight, p. 227)

Entrepreneurship entails constructing the belief (or the opinion) that allocating resources in a particular, novel way will lead to a profitable enterprise (Foss and Klein, 2012; Knight, 1921). The opinion needs construction by the entrepreneur due to the uncertainty experienced at the time of launching a new venture (Alvarez and Barney, 2007; McMullen and Shepherd, 2006). In many cases, a new venture will introduce an element of novelty or a high degree of uniqueness that will render some of the previous experiences irrelevant (Knight, 1921). This, in turn, prohibits a rational probabilistic analysis and the entrepreneur faces uncertainty rather than risk.

The entrepreneur's cognitive response to the uncertainty is judgment. After a comprehensive review of key theories of entrepreneurship, Foss and Klein (2012) identify judgment as her distinctive function. The individual imagines a new way of organizing resources such that the offering of the new venture is worth more than the associated costs (Klein, 2008; Mahoney and Michael, 2005). During the period of venture development, the judgment of the entrepreneur guides the resource allocation decisions since reliable data about the operations of the venture is not available to her (Dimov, 2007). We posit that such judgment concerning the future success of the venture is a cognitive act in the mind of the entrepreneur.

In this research, we model entrepreneurial judgment as a cognitive process that operates on the knowledge structures of the entrepreneur as she responds over time to her own "image of a future state of affairs” (Knight, 1921, p. 201). Subsequently such knowledge structure guides her 
resource allocation decisions for the success of the venture. Previous research in entrepreneurial cognition examined several knowledge structures individuals employ as they make decisions under conditions of uncertainty. Cognitive scripts (Mitchell et al., 2000), prototypes (Baron and Ensley, 2006), and structural mapping (Grégoire and Shepherd, 2012) are some examples of knowledge structures in use. However, scripts, prototypes, and structural mapping do not emphasize causality directed at profits whereas entrepreneurial judgment invariably contains an appreciation of the entrepreneur's subjective opinions about what key factors should be favored. Hence, we propose that entrepreneurial judgment as determining resource allocation under uncertainty can be better theorized using a different type of knowledge structure, a causal map. The causal map is not judgment itself, but a knowledge structure that is employed as one exercises entrepreneurial judgment. As Knight alludes in the opening quote, the two attributes of the causal map play an important role as her judgment guides the entrepreneur in allocating resources toward the new venture. The shape of the causal map (i.e., selectivity of entrepreneurial judgment) refers to the discriminating nature of the key factors in affecting success for the particular venture and guides the entrepreneur prioritize investment areas. The strength of the causal map (i.e., conviction in entrepreneurial judgment) refers to the confidence of the entrepreneur in the map itself and encourages her to act.

We contribute to entrepreneurship research by developing a theory of entrepreneurial judgment as a cognitive process operating on a causal map and examining its two attributes: selectivity and conviction. Second, we develop an empirically testable model of entrepreneurial judgment that reflects what success factors would lead to profitability (cf. Michael, 2007). Despite its prominence in conceptual discourse, entrepreneurial judgment in this sense has not been empirically modeled and tested before. Using a data set of 524 U.S. nascent entrepreneurs 
collected in the Panel Study of Entrepreneurial Dynamics (PSED) II project, we find that venture-specific experience, along with the uncertainty of the venture and the cognitive disposition of the individual, affects entrepreneurial judgment. Third, our findings demonstrate that as entrepreneurs accumulate venture-specific experience their causal maps evolve with respect to their shape and strength. Fourth, we identify specific conditions of uncertainty and cognition that will affect the shape and strength of the causal maps differently.

\section{THEORY AND HYPOTHESES}

When the entrepreneur believes that she discovered or created an opportunity, she constructs a belief or an opinion about the future prices of a product that has not been produced yet (Alvarez and Barney, 2007). This opinion is a forward-looking belief or foresight and the way to get there successfully is mostly an imagination in the mind of the entrepreneur (Foss and Klein, 2008). The entrepreneur has to choose strategic actions based on the imagined consequences (Batstone and Pheby, 1996; Shackle, 1970). A more rational decision-making method to choose actions would be to predict the outcomes and calculate the expected values; however, the lack of relevant, objective historical data constrains this calculation severely (Knight, 1921) ${ }^{1}$. Therefore, the entrepreneur is forced to make judgments based on her venture idea and her subjective knowledge of the relevant environment (Eckhardt and Shane, 2003; Knight, 1921; Mahoney and Michael, 2005). She tries to make sense of the ambiguous signals in the new venture environment, update her knowledge structure, and imagine a course of strategic actions that will lead the venture to profitability in an uncertain future.

\footnotetext{
${ }^{1}$ According to Knight, imperfect knowledge of the future presents three types of unknowns: 1 . Outcome is unknown but a probability distribution can be computed a priori (e.g., throwing a dice) 2. Outcome is unknown but a probability distribution can be constructed reasonably based on empirical observation of similar past events (e.g., destruction of a building by fire) 3. Outcome is unknown and a set similar past events is not available (e.g., many entrepreneurial decisions in a new business setting). Knight classifies the first two types as risk and calls only the third type as uncertainty. In uncertain situations, entrepreneurs make subjective estimates to guide their decisions.
} 
The entrepreneur has to bear the burden of uncertainty in order to act on a novel opportunity; however, uncertainty manifests itself as relative ignorance and doubt in the mind of the entrepreneur (McMullen and Shepherd, 2006). The entrepreneur is partially ignorant when she possesses an imperfect knowledge of the future (Knight, 1921) and she does not know the probability distribution of the potential outcomes of her actions (Langlois, 2007). When she is entirely ignorant, she might not perceive even the necessity to consider and judge what strategic factors might affect the profitability of her new venture. Ignorance of the entrepreneur is partially alleviated when the entrepreneur is exposed to new venture environment so that her consideration set of possible actions is augmented with new elements. In a complementary but separate manner, the entrepreneur experiences doubt because it requires a certain level of willingness to bear the burden of uncertainty to act on it (Knight, 1921; Schumpeter, 1934). The more confident she feels about her judgment, the less doubtful, hence the more willing she will be to bear the uncertainty (McMullen and Shepherd, 2006). In the next section, we discuss how entrepreneurs use alternative cognitive mechanisms against ignorance and doubt in entrepreneurial judgment.

\section{Causal map as the underlying knowledge structure}

We conceptualize entrepreneurial judgment as a cognitive process through which venturespecific knowledge of the entrepreneur is organized to guide her resource allocation decisions. Entrepreneurial cognition literature in recent years has begun to investigate the puzzle of knowledge structures in the mind of the entrepreneur (Grégoire et al., 2011; Mitchell et al., 2007). In fact, Mitchell and colleagues define entrepreneurial cognition as "the knowledge structures that people use to make assessments, judgments, or decisions involving opportunity evaluation, venture creation, and growth” (p. 97, emphasis added). Previous research 
investigated several types of knowledge structures as potential cognitive devices entrepreneurs use when they make decisions. For example, when they make opportunity discovery and feasibility assessments entrepreneurs are shown to access certain cognitive scripts (Mitchell et al., 2002b). In a cognitive psychology based model, Baron and Ensley (2006) develop the concept of an opportunity prototype. According to this research stream, entrepreneurs use pattern matching when they assess economic events around them and compare the events against their opportunity prototype. Structural alignment and analogies constitute another set of cognitive devices that entrepreneurs are proposed to operate on their knowledge structures. According to the former theory, entrepreneurs make similarity comparisons between technology and market combinations. They identify opportunities depending on the strength of superficial and structural similarities (Grégoire et al., 2010; Grégoire and Shepherd, 2012). According to the results of another real-time experiment, individuals consider analogical properties such as the cognitive distance between domains when they evaluate the profit potential of opportunities (Uygur, 2016).

This recent literature highlights the significance of knowledge representation for entrepreneurial cognition; however, they do not capture the notion of entrepreneurial judgment which guides resource allocation in the face of uncertainty (Casson, 1982; Foss and Klein, 2012; Knight, 1921). Extant theories are incomplete because of their relative inattention to uncertain causal connections. Entrepreneurial judgment reflects an internal negotiation concerning what strategic investments are most likely to lead her new venture to profits. This internal negotiation relies on not only her existing knowledge but also subjective beliefs and opinions. We advance that entrepreneurs employ a knowledge structure like a causal map that represent their judgments about the most critical factors for profitability. 
In cognitive sciences, a causal map is "an abstract representation of the causal relationships among kinds of objects and events in the world" (Gopnik and Glymour, 2002). It is a specific type of cognitive map (Kitchin, 1994; Thagard, 1992; Tolman, 1948) that associates causal connections between concepts and they "express the judgment that certain events or actions will lead to particular outcomes" (Nadkarni and Shenoy, 2001). Individuals construct causal maps that represent their theories of how things work so that they can predict and determine a course of actions ex ante under complexity and uncertainty. In an entrepreneurial situation, entrepreneurs make judgments by employing their causal maps that connects several aspects of an opportunity to expected profitability (Castrogiovanni, 1996; Delmar and Shane, 2006). A causal map of entrepreneurial judgment would hold subjective probability assessments of key success factors in relation to the expected profits from a venture. We focus on two attributes of the causal map that connects factors to expected success: the shape and the strength.

First, by shape, we mean the relative importance of the factors and how they compare against each other. A flat shaped causal map would suggest that the entrepreneur believes out of ignorance that all factors are equally important for potential success of the venture. By contrast, a rugged shaped causal map would imply some refinement such that it identifies subjectively the most critical factors for success from a larger set of all possible factors. We call this selectivity of entrepreneurial judgment. The more rugged the causal map is the more discriminating of the key success factors the entrepreneur has become for her venture ${ }^{2}$. Nonetheless, knowing something is both conceptually different and neurologically separate from the "feeling of knowing” (Burton, 2009) or "the amount of confidence" in judgment (Knight, 1921). Second, by strength, we mean

\footnotetext{
${ }^{2}$ It is possible that highly selective judgment (or rugged causal map) turns out accurate and results in a positive outcome ex post. However, at the time of judgment it is also possible that focusing on fewer critical factors is ungrounded and mistaken. In this study, we do not theorize on the normative implications but examine how entrepreneurs make judgments differently in the present.
} 
how clear or blurry the causal map is to the entrepreneur. A map that is free of doubt will appear strong and clear than a highly doubtful one. We capture such faith of the entrepreneur in her judgment conviction in entrepreneurial judgment. The more conviction the entrepreneur possesses in her causal map the more likely her strategic investment decisions will reflect those judgments.

\section{Evolution of entrepreneurial judgment}

Previous literature suggests that opportunity ideas evolve over time. In criticizing the singular discovery view, Dimov (2007) argues that entrepreneurial insight does not happen only once but instead the ideas change over time through a series of insights. When the opportunity is identified at first, the entrepreneur constructs a causal map and exercises her judgment at the time. During the period immediately following the initial epiphany, we expect the knowledge of the entrepreneur specific to this venture to be limited and the causal map to be simple. However, as the entrepreneur works for the development of the venture, her experience accumulates and induces learning, which implies a change in underlying knowledge structure (Holcomb et al., 2009) into a more refined causal map. In agreement with entrepreneurial cognition literature (Corbett, 2002) we hypothesize how venture-specific experience, entrepreneurial uncertainty, and cognitive dispositions affect this process in the following sections.

\section{Venture-specific experience}

Experience turns into expertise when the underpinning knowledge structure is refined in the context of the new venture. As the entrepreneur accumulates venture-specific experiences, learning occurs as those experiences cause a transformation of existing knowledge structures in the mind (Holcomb et al., 2009; Kolb, 1984). Feedback from stakeholders and the entrepreneur's insights from personal endeavors will facilitate such transformation. In particular, the individual 
will have a richer set of experience to update her subjective assessment of what factors are likely to lead the venture to profitability. Haynie et al. (2012) demonstrate that entrepreneurs actually change the way they think in response to feedback. Specifically in our conception, we propose that the causal map related to the success of the venture is modified after the initial discovery as the entrepreneur accumulates experience. The more time an entrepreneur spends working for the venture the more learning occasions there will be (Corbett, 2005). In turn, the shape of the causal map will look more rugged than flat as the entrepreneur's opinions reflect her venture experiences. It is possible that some of these experiences might be misleading and inaccurate due to sustained uncertainty. Nevertheless, their refined causal map will be more selective so that the entrepreneur will be able to judge a smaller set of success factors as critical.

H1a. More time invested in working for the venture leads to more selective entrepreneurial judgment

Similarly, we expect that increased experience with the venture will help entrepreneur be certain in her judgment. Effective assimilation of new experiences by the entrepreneur into the existing knowledge structure set deepens her own understanding of the most critical factors for new venture success. When the new experiences are more tightly coupled with the existing knowledge set (Holcomb et al., 2009), such assimilation would strengthen the entrepreneur's conviction in that judgment. Moreover, the intensity of the entrepreneur's effort makes a difference. If the entrepreneur spends a lot of time and energy on the venture, the connections in the memory will be stronger and she will see the causal map more clearly. Hence, we posit that: H1b. More time invested in working for the venture leads to stronger conviction in entrepreneurial judgment 
The amount of time invested in the venture may not fully differentiate among the very varied types of venture-specific experiences the entrepreneur might have had. Different experiences lead to "increasingly focused and refined mental frameworks" (Baron and Ensley, 2006: 1341). From initial conception to implementation, any "act of entrepreneurship is a change in the content of the entrepreneur's knowledge in some area” (Minniti and Bygrave, 2001: 7). One common activity entrepreneurs go through is the preparation of a business plan (Brinckmann et al., 2010; Brinckmann and Kim, 2015). Business planning activities are directed at validating new business ideas, anticipating future developments, and determining an appropriate course of action (Mintzberg, 1991). The business planning approach reflects an entrepreneur's belief that careful analysis prior to entrepreneurial action helps in developing better insights and useful knowledge which can improve new venture performance (Delmar and Shane, 2003). Business planning is based on the assumption that entrepreneurs have pre-existing goals (Sarasvathy, 2001). Initial beliefs and goals, however, may change over time with business planning experience. Collecting and evaluating the evidence to justify initial claims in a business plan under conditions of uncertainty is likely to affect subjective assessment of critical factors and the causal map in the mind of the entrepreneur. As the entrepreneur articulates the details of the venture idea in formal business planning, some causal factors will lose their importance while others will gain, resulting in a change in the shape of her causal map. Hence, we posit that: H2a. Formal business planning in venture development leads to more selective entrepreneurial judgment

From a learning perspective, business planning is characterized as a deductive learning approach that is internally directed, relying on an entrepreneur's own judgment and prediction which contrasts to an inductive approach that is externally oriented and seeks to derive insights 
from the interactions with various stakeholders (Regnér, 2003). Further, business planning reflects a proactive learning activity as the entrepreneur establishes causal relationships prior to action (Castrogiovanni, 1996). If the business planning experience supports the validity of the new business idea, the confidence of the entrepreneur in the venture will augment (Dimov, 2010). Hence, in parallel to the hypotheses above, we expect that formal business planning will also lead to stronger conviction in judgment. In a complex environment, deep knowledge structures developed in various experiences can be helpful in trusting their own judgments (Weick and Roberts, 1993). This will be the case especially when the entrepreneur's knowledge structure is subjectively supported by business planning experience regardless of the time spent on the venture. Subsequently, the exercise of formal business planning itself will lead to a cognitively more salient causal map and thus a stronger feeling of knowing. H2b. Formal business planning in venture development leads to stronger conviction in entrepreneurial judgment

\section{Entrepreneurial uncertainty}

In uncertain situations where a set of similar past events is not available, entrepreneurs need to act according to opinion, which is "neither entire ignorance nor complete and perfect information, but partial knowledge” (Knight, 1921). Entrepreneurs acquire some partial knowledge as they overcome complete ignorance and construct their estimates for imagined outcomes. However, perceived uncertainty by an individual can lead to doubt, disbelief in the feasibility of the business idea, or distrust in her ability to successfully develop a new venture (Dimov, 2010). In order to overcome these adverse states of mind, entrepreneurs exercise judgments about future business environments, key success factors in the business, and their effects on the new venture. 
Our expectations about the effect of uncertainty on judgment are more complex than our expectations about experience. When the entrepreneur perceives high uncertainty, it will be difficult for her to make sense of new experiences (Weick and Roberts, 1993). Hence, we expect those entrepreneurs who perceive high uncertainty would not effectively discern the most critical factors for the success of the venture, leading to less focused causal maps. The shape of their causal maps will remain flatter because they will continue to experience difficulty in subjectively assessing which factors are more likely to affect profitability than others. As a result, we expect the way they exercise their judgment in resource allocation will be less selective. Our expectation is consistent with the Minniti and Bygrave (2001) model, which suggests that the difficulty of the problem determines whether the entrepreneur can find the optimal knowledge combination or not.

More specifically, we investigate two different types of uncertainty in a given entrepreneurial situation. One is to look at it from the perspective of task uncertainty the entrepreneur perceives as this will influence the "uniqueness of the instances" subjectively experienced by the entrepreneur. If the new venture is an outgrowth of the entrepreneur's current work activity, then she will classify some of the activities as previously encountered decisions and perceive less uncertainty in her venturing tasks. Her causal map will likely reflect the characteristics of similar previous experiences and she will be able to make discriminating judgments rapidly. In contrast, a completely new domain will represent a high task uncertainty situation, and her judgment will remain less selective for a longer time.

H3a. Task uncertainty of the venture leads to less selective entrepreneurial judgment Another way to conceptualize the uncertainty is to consider the novelty of the product from the customer's perspective in the market (Dahlqvist and Wiklund, 2012). If the product is 
completely unknown to the customers, the entrepreneur will be facing high customer uncertainty. Lack of reliable information about the future customer reactions will make it difficult for the entrepreneur to determine what to focus on (Shackle, 1970). Due to the novelty of the offering, the entrepreneur may receive diverse and mixed feedback from the prospective customers. In such a situation, assimilating newly acquired information with existing knowledge structure is challenging (Holcomb et al., 2009). Regardless of the entrepreneur's familiarity with the task, customer uncertainty can hamper or delay refinement of her causal map. With a flatter rather than rugged causal map, we expect that the entrepreneur will find it difficult to discern the most critical factors for the success of the venture.

H4a. Customer uncertainty of the venture leads to less selective entrepreneurial judgment In contrast, we expect the relationship between uncertainty and conviction to be the opposite. In a venture with high task uncertainty, the entrepreneur’s causal map, however unfocused it may be, will be more "valuable" for judgment. Knight had the intuition that an entrepreneur's subjective feeling of confidence, which we call conviction, was a significant determinant of action. Recent research in cognitive sciences has identified the factors and circumstances influencing such conviction of an individual. For instance, when it is necessary to form a judgment under high uncertainty, people do not usually retrieve all their knowledge (Schwarz and Vaughn, 2002). Prior research on availability heuristic suggests that people stop cognitive processing when they bring an adequate extent to working memory (Tversky and Kahneman, 1973). Instead, they resort to a sense of certainty along with that judgment that is based on incomplete knowledge (Holcomb et al., 2009). Similarly, Minniti and Bygrave (2001) suggest that entrepreneurs prematurely converge on actions that promise desirable outcomes early in the process. They claim that in highly uncertain circumstances the risk of settling on an 
under-developed knowledge is higher. When the entrepreneurs' causal maps remain ambiguous due to highly uncertain tasks, their limited knowledge will be used intensively to discern the critical success factors. In other words, the entrepreneur's causal map will be stronger regardless of its shape when the perception of task uncertainty is higher. Therefore, we expect a positive relationship between task uncertainty and conviction in the judgment of the entrepreneur. H3b. Task uncertainty of the venture leads to stronger conviction in entrepreneurial judgment Similarly, we conceive of customer uncertainty having a positive effect on conviction in judgment. While individuals are relatively comfortable in situations when the probability distributions are known (i.e., Knightian risk), cognition research demonstrates that people react differently in different contexts of Knightian uncertainty. Ellsberg paradox (1961) shows individuals feel more comfortable when the probability distributions are completely unknowable by anyone than a situation in which the probability distributions might be available to others (Chow and Sarin, 2002). When the venture's offering is entirely new to the world, the probable outcomes are unknowable to others and this will create a feeling of comfort for the entrepreneur and trigger various cognitive responses.

Perceived uncertainty can influence cognitive processing by the way of excessive reliance on heuristics (Holcomb et al., 2009). When facing novel settings such as an unknown product offered to the customers, entrepreneurs will use heuristics instead of deliberate analysis. In addition to the availability heuristic, entrepreneurs may use anchoring and adjustment heuristics (Tversky and Kahneman, 1974). Even though their knowledge may be limited, they will use their prior experience with other product categories to anchor their expectations (Holcomb et al., 2009) and justify their judgments. Such cognitive responses will not help her refine her causal map, which will remain relatively flat. However, the entrepreneur's feeling of knowing will be 
stronger with the use of heuristics. That in turn will lead to a sense of confidence and stronger conviction in judgment of the entrepreneur.

Customer uncertainty captures a more exogenous nature of uncertainty than task uncertainty. When the product is truly unique in the market and unknown by the prospective customers, their reactions are difficult to predict by the entrepreneur. In contrast, facing task uncertainty, entrepreneurs can focus on internal activities over which they have some control and can exert efforts to improve their judgments. Facing customer uncertainty, however, entrepreneurs have limited prospects to affect or learn in order to refine their causal maps. Thus, we expect they would often resort to the aforementioned heuristics to cope with customer uncertainty. H4b. Customer uncertainty of the venture leads to stronger conviction in entrepreneurial judgment

\section{Cognitive dispositions}

Entrepreneurial judgment is a cognitive process and we expect the individual's cognitive dispositions to influence it. Cognitive dispositions consist of "consistent individual differences in preferred ways of organizing and processing information and experience” (Messick, 1976: 5).

Previous research identified several cognitive dispositions as influential in decision making in entrepreneurial situations. Allinson et al. (2000) found a difference between intuitive and analytical cognitive styles when these individuals engaged in entrepreneurial behaviors. Similarly, Corbett (2002) found that intuitive cognition was more conducive to opportunity identification than analytical cognition. Similarly, we expect cognitive characteristics to have an effect on entrepreneurs' refinement of their causal maps and their conviction in those judgments. Specifically, we examine two characteristics that have been investigated previously in the entrepreneurship literature: entrepreneurial self-efficacy and decisiveness. 
Entrepreneurial self-efficacy refers to “a person’s confidence about his/her ability to perform the various tasks and roles relevant to entrepreneurship” (Cassar and Friedman, 2009). It is a domain-specific application of the broader social cognitive theory on self-efficacy (Bandura, 1986). Individuals with higher entrepreneurial self-efficacy are more confident in their abilities to perform the activities related to new business venturing (Drnovšek et al., 2010). When the entrepreneurs are more confident in their abilities, they spend more effort toward judgment tasks, for example collecting and analyzing data and identifying risks associated with the venture (Trevelyan, 2011). In this regard, we expect that highly self-efficacious entrepreneurs are more likely to refine their causal maps and discern the most critical success factors in the venture. H5a. Entrepreneurial self-efficacy leads to more selective entrepreneurial judgment

Beyond helping the entrepreneur discern among critical factors for venture success, entrepreneurial self-efficacy will also augment an individual's feeling of knowing (Burton, 2009). High level of self-efficacy leads to a sense of control the individual has over the process (Bandura, 1986). Highly self-efficacious individuals are more likely to engage in practices that will remove doubts about entrepreneurial judgment (Baron and Henry, 2010). The doubt surrounding the uncertainty is one of the critical barriers to further entrepreneurial behavior (McMullen and Shepherd, 2006). When the entrepreneurs experience less doubt and more confidence in their abilities to perform the venturing tasks, they are more likely to settle on or believe the validity of their own judgments of the key success factors. Higher levels of confidence tend to reduce search effort (Cooper et al., 1995) as people usually form "opinions as to their own capacity to form correct judgments” (Knight, 1921). Hence, we propose that highly self-efficacious entrepreneurs will perceive stronger conviction in their judgments. H5b. Entrepreneurial self-efficacy leads to stronger conviction in entrepreneurial judgment 
Entrepreneurial decisiveness is the tendency of the individuals to make decisions quickly in the venturing tasks. The broader concept of decisiveness in the psychology literature is a component of the need for cognitive closure. An individual with a high need for cognitive closure is more likely to form judgments based on a limited information set (Kruglanski, 1989). Decisive individuals can make decisions more easily and commit to them cognitively because they terminate search for further information quickly (Dougherty and Harbison, 2007). It should be noted again that we do not presume any validity of the decisions the entrepreneur makes. Depending on how knowledge is used (i.e., cognition), it may help or stifle the entrepreneurial path (Ward, 2004). When decisive individuals perceive high levels of information determinacy in their environment (Forbes, 2007), they can easily make sense of why some factors of competition are more important than others. Hence, we hypothesize that someone who identifies as decisive is more likely to have a narrow causal map of success factors than others who identify themselves as indecisive. Regardless of its accuracy, the refined causal map is critical to the judgments the entrepreneur makes such as resource allocation decisions.

H6a. Entrepreneurial decisiveness leads to more selective entrepreneurial judgment

Similarly, entrepreneurial decisiveness is expected to strengthen the conviction of the entrepreneur in her judgment. Highly decisive individuals have less fear of making judgmental errors. They make decisions under uncertainty quickly without such fear (Neuberg et al., 1997). As part of the need for closure characteristic, decisiveness is likely to lead to "inclinations to seize and then freeze on early judgmental cues” (Kruglanski and Webster, 1996 :278). That effect will increase their confidence in their understanding of key success factors in the venture. Potentially conflicting information that may lead to doubt with the causal map is less likely to arise because the decisive entrepreneur will cease search for new information sooner (Leaptrott 
and McDonald, 2008). That in turn will lead to a sense of certainty and stronger conviction in the judgment of the entrepreneur regardless of its accuracy.

H6b. Entrepreneurial decisiveness leads to stronger conviction in entrepreneurial judgment

\section{METHOD}

\section{Data and sample}

This study uses a data set from the Panel Study of Entrepreneurial Dynamics (PSED) II which was designed to offer valid and reliable data on the process of new business formation. PSED II began in 2005 with the identification of a cohort of 1,214 nascent entrepreneurs chosen from a representative sample of 31,845 adults from the U.S. population (Reynolds and Curtin, 2008). To identify nascent entrepreneurs from initial telephone surveys, each respondent was asked a series of questions about his or her current activities. Specifically, the following three criteria were employed in the PSED II project (Screener): they performed some start-up activity in the past 12 months, they expect to own all or part of the new firm, and the initiative had not had a period of profitability in the past 12 months (Reynolds and Curtin, 2008). Those that satisfy all three criteria are considered nascent entrepreneurs and invited to participate in a detailed interview. About 87 percent of those identified as active nascent entrepreneurs in the screening agreed to participate in the PSED II interviews. Data from the initial interview (Wave A survey until March 2006) are used for empirical analysis and robustness test in this study. From the initial sample, we identified 524 single-owner entrepreneurs for the purpose of this study.

In the final sample, $60 \%$ are men, and the average age is $44.35 \%$ have finished college, and $36 \%$ of them are married. $56 \%$ have no prior start-up experience and $17 \%$ have no industry experience of the new business. Only 5\% of the sample entrepreneurs own more than one business, and 58\% are employed in full-time work. 75\% have spent more than 100 hours in the 
new venture and only $14 \%$ have developed a formally rewritten business plan for the new venture.

Regarding the characteristics of the new ventures, $23 \%$ of the ventures are reported as $R \& D$ intensive. While 16\% (26\%) of the new ventures are from the entrepreneurs' current (previous) work, $29 \%$ are from research or ideas from other people. $17 \%$ of the ventures offer completely new or unfamiliar product or service to the target customer, but $50 \%$ offer the existing ones. While there is substantial diversity in the amount of resource endowments, only $7 \%$ have received external funding from financial institutions or other investors.

\section{Measures}

In measuring individual-level knowledge structures, survey-based measures have been considered appropriate for assessing knowledge acquisition (Yli-Renko et al., 2001) and have been effectively used in entrepreneurship research (e.g. Naldi and Davidsson, 2013; Zahra et al., 2000). As shown in Figure 1, we measure refinement of the causal maps (i.e., selectivity and conviction in entrepreneurial judgment) with ten survey questionnaires reflecting nascent entrepreneurs' assessment of key success factors in their new ventures. In particular, the dependent variables should represent the evolution of the entrepreneur's entrepreneurial judgment on business opportunity and important factors of competition in the market of new ventures. Two cognition measures were constructed to capture different components of entrepreneurial judgment: selectivity and conviction.

\section{Figure 1}

\section{Selectivity of entrepreneurial judgment}

First, in order to measure selectivity of the entrepreneur's judgment, the respondents were asked to assess ten factors that may be important for success of their ventures. In order to capture the 
theoretical construct of the selectivity of judgment we developed a measure based on how selective the entrepreneur was in choosing among the ten factors. According to our reasoning, individuals who have absolutely no knowledge about an opportunity would not be able to make discerning judgments among the ten factors. In Figure 1, which illustrates some hypothetical judgments, Individual A represents an "ultimate novice.” This entrepreneur answered all questions as “neither important nor unimportant.” In contrast, individuals C and D made some discerning judgments about which factors may lead to the success of the venture. To capture that variation, we first calculate the standard deviation across the ten items. Then, in order to normalize with respect to the mean, we calculate the coefficient of variation (COV) by dividing the standard deviation by the mean. We maintain that this score reflects selectivity of the entrepreneur's judgment since it is sensitive to the ruggedness of the individual's causal map. For instance, individual B who claimed that all factors were very important still receives a zero score since his judgment is not discriminating at all.

\section{Conviction in entrepreneurial judgment}

The difference between the assessments of individual A and individual B, however, is important to capture. The shape of their causal maps are identical with zero selectivity but they are the extreme opposites in the strength of the causal map. As the ultimate novice, individual A represents having no opinion at all. However, individual B has strong opinions even though those opinions do not constitute a refined judgment in terms of selectivity. More generally, lacking selectivity does not mean lacking a "strong opinion" or conviction in the judgment. For instance, a novice may represent having no opinions at all by choosing 3s ("neutral”) for all ten factors while another novice may have stronger opinions by choosing all 5s ("highly important”) in her 
judgment. To capture that variation in conviction we calculate the sum of absolute differences from the neutral position of 3 for all ten factors.

\section{Venture-specific experience}

Our measures of venture-specific experience are in line with the entrepreneurship literature of the experiential learning perspective (cf. Delmar and Shane, 2006; Dokko et al., 2009; Huckman and Pisano, 2006). We measure venture-specific experience by considering both quantitative (i.e., time spent) and qualitative (i.e., business planning) aspects of entrepreneurs' experience in the new venture. Because the distribution of the measure of total hours spent in the new venture was skewed, we performed log transformation procedures (Delmar and Shane, 2006). We measure the existence and form of business planning by using a dummy variable with a value of one if a business plan is formally prepared and a value of zero otherwise (Castrogiovanni, 1996; Delmar and Shane, 2003).

\section{Entrepreneurial uncertainty}

Drawing on prior research (e.g. Sapienza and Gupta, 1994), we measure two different types of uncertainty in the new venture: internal task (operational) uncertainty and external customer (market) uncertainty. Since uncertainty in effectively performing venture-specific tasks can influence nascent entrepreneurs' judgment, we measure task uncertainty based on respondents' self-reported explanation about the origin of the new business in a Likert-like scale with values ranging from 1 (from your current work: lowest task uncertainty), 2 (from your previous work), 3 (from your separate business), 4 (from your hobby or recreational pastime) to 5 (from others' research or idea: highest task uncertainty). Following Newbert et al. (2012), we operationalized customer uncertainty using a dummy variable with a value of one for high customer uncertainty 
if all of potential customers consider this product or service of the new venture new and unfamiliar, and a value of zero otherwise.

Cognitive disposition

Among the cognitive characteristics identified in prior PSED-based research (e.g. Cassar and Friedman, 2009; Townsend et al., 2010), we measure two different cognitive dispositions of nascent entrepreneurs: entrepreneurial self-efficacy and decisiveness. Both variables are measured and coded in a Likert scale from 1 (Strongly disagree) to 5 (Strongly agree) and represent highly self-efficacious and decisive individuals with higher values. To be consistent with the previous literature, the average value of the three PSED II items is used to measure entrepreneurial self-efficacy (Cronbach’s alpha $=0.70$ ).

\section{Control variables}

In order to control for effects that might otherwise influence a nascent entrepreneur's judgment on the most critical factors for profitability in the new venture, we use the following individuallevel, venture-level, and environment-level control variables.

To be consistent with recent empirical approaches (e.g. Uy et al., 2012), we control for prior founding experience by using the number of business ventures entrepreneurs helped to start as an owner or part-owners. To control for prior managerial experience, we include a continuous variable of the years of managerial, supervisory, or administrative responsibilities. In order to control for the intensity and transferability of venture-specific learning by portfolio entrepreneurs (Westhead et al., 2005), we measure business scope with a continuous variable of the number of other businesses owned by each respondent. In addition, we include a dummy variable representing current employment status. Since formal academic education is the most common operationalization of general human capital in the entrepreneurship literature (Brüderl et al., 
1992), we control for the entrepreneur's educational attainment with a dummy variable of indicating a minimum of a four-year college degree (Naldi and Davidsson, 2013).

Following Naldi and Davidsson (2013), we control for the extent to which entrepreneurs need to learn different skills and insights to serve target customers outside their local markets. We include two continuous variables that represent the percent of target customers being either local or international. Further, since friendly and supportive founding environment can facilitate domain experiences (Powell and Eddleston, 2013), we control for the characteristics of respondents' community by including a continuous variable with the mean value of the following five Likert scale items: social norms and culture of the community, bankers and other investors in the community, friends, and relatives. We also control for opportunity attractiveness in two different ways: entrepreneurs' growth expectancy on the new business $(2006,2010)$ and investor's expectancy based on external funding received from financial institutions or other people. Further, we control for respondents' growth intention (Newbert et al., 2012).

To control for the development phase of the new venture and thereby reduce bias due to leftcensoring (Yang and Aldrich, 2012), we include a dummy variable of indicating whether a federal income tax return has ever been filed for the new business. Finally, we control for the effects of industry similarity between new ventures by using respondents' assessment of R\&D intensity with a dummy variable indicating whether spending on R\&D is a major priority for this new business, and by including 2-digit SIC codes (Toft-Kehler et al., 2013).

\section{RESULTS}

Table 1 provides the descriptive statistics and the correlations of the variables utilized in the analysis. Correlation coefficients are generally modest, and no signs of collinearity are detected in the analysis. In particular, the two measures of entrepreneurial judgment are not significantly 
correlated $(r=0.04)$. This suggests that selectivity and conviction indeed represent different aspects of entrepreneurial judgment although they are calculated from the same PSED II items based on respondents’ assessment of key success factors in their new businesses. Accordingly, we examine the two aspects of judgment separately, and use hierarchical multiple regressions to test hypotheses.

Table 1

Table 2 reports the main regression findings for the relationships between a set of independent variables and the first dependent variable, selectivity of entrepreneurial judgment (i.e., the coefficient of variations in relative importance of ten different factors of competition in the market of new venture). Column 1 presents the estimates of the base model that includes only control variables. Columns 2 to 7 differ from column 1 in that each model includes an explanatory variable of experience (time spent in the venture or formal business planning), uncertainty (task or customer uncertainty), or cognition (entrepreneurial self-efficacy or decisiveness) examining the hypothesized relationships, respectively.

\section{Table 2}

The estimates presented in Table 2 suggest that the hypothesized effects on selectivity of entrepreneurial judgment are explained in part by venture-specific experience and cognition of nascent entrepreneurs. Specifically, the coefficients of experience measures (time spent and formal business planning in columns 2 and 3) are both positive and statistically significant which support for Hypotheses 1a and 2a. Further, the coefficient of our measure of cognition (entrepreneurial decisiveness in column 7) is also positive and significant as predicted, supporting for Hypothesis 6a. However, we do not find empirical support for Hypothesis 5a 
(entrepreneurial self-efficacy in column 6), and Hypotheses 3a and 4a (task uncertainty and customer uncertainty in columns 4 and 5).

The results of control variables in Table 2 are also noteworthy. Our measure of growth intention has a negative and significant effect on selectivity of entrepreneurial judgment in all models. In contrast, academic experience measured by college education show a positive and significant effect consistently across all models. We also find that supportive founding environment has a positive and significant effect on selectivity of entrepreneurial judgment, while the effects of external funding and R\&D intensity are negative and significant in all models.

Table 3 provides the regression results explaining the relationships between the same independent variables and the second dependent variable, conviction in entrepreneurial judgment (i.e., the sum of absolute difference from the neutral value for ten different factors of competition in the market of new venture). The results in Table 3 indicate that the hypothesized effects on conviction in entrepreneurial judgment are explained by venture-specific experience, cognitive disposition of entrepreneurs, and entrepreneurial uncertainty. Specifically, the coefficients of experience measures (time spent and formal business planning in columns 2 and 3) are both positive and statistically significant which support for Hypotheses $1 \mathrm{~b}$ and $2 \mathrm{~b}$. The coefficient of entrepreneurial decisiveness in column 7 is also positive and significant, supporting Hypothesis 6b. Hence, we find that venture-specific experience and entrepreneurial decisiveness have similar impacts on selectivity and conviction in nascent entrepreneurs' judgments. In addition, we find different results between selectivity and conviction in entrepreneurial judgment. The coefficient of customer uncertainty in column 5 is positive and significant in Table 3, supporting Hypothesis 4b. Further, the coefficient of entrepreneurial self-efficacy is positive and significant 
in column 7, which provides support for Hypothesis 5b. However, we do not find empirical support for Hypothesis 3b regarding the negative impact of task uncertainty as the corresponding coefficient in column 4 is not statistically significant.

\section{Table 3}

The results of control variables in Table 3 suggest that, in contrast to what we find in Table 2 about selectivity of entrepreneurial judgment, the measure of growth intention has a positive and significant effect on conviction in entrepreneurial judgment, but the effect of college education is not significant. Further, our measure of business portfolio (serial entrepreneurs) in Table 3 shows a negative and significant effect on conviction in entrepreneurial judgment. The effects of funding environment and R\&D intensity are reversed from those in Table 2.

An estimation problem arises in testing the causal effects of cognitive disposition of nascent entrepreneurs since entrepreneurial judgment is a cognitive process. Standard OLS regressions of observational data may fail to yield reliable estimates of the hypothesized relationships due to potential endogeneity. In particular, there could be omitted variable bias where other unobserved cognitive characteristics of the individual are correlated with cognitive disposition and entrepreneurial judgment simultaneously. When such omitted variables are observable but missing in the test model, there could be respondent selection bias.

In order to ensure that our findings are robust to such biases, we performed the Durbin-WuHausman test for endogeneity so that we could decide whether it was necessary to use an instrumental variable (IV) approach (Davidson and MacKinnon, 1993). From the PSED II Section Y: Respondents' Characteristics we identified the following six variables suitable for instruments both conceptually and statistically (Stock, 2001): AY1 (“I consider myself a loner”); AY2 ("Whatever emotion I feel on the inside tends to show on the outside"); AY5 ("If I start this 
new business, it will help me achieve other important goals in my life”); AY13 ("I enjoy the uncertainty of going into a new situation without knowing what might happen”); AY15 (“I dislike it when a person's statement could mean many different things”); and AY16 ("When thinking about a problem, I consider as many different opinions on the issues as possible”). The Durbin-Wu-Hausman test indicates that the OLS estimates are consistent and IV regressions are not necessary. Based on the test results, we find our findings are robust to potential biases.

We did not theorize any particular relationship between the explanatory variables in hypothesis development. As a post hoc analysis, however, we further investigated whether the test results were robust to their additive or multiplicative relationships and potential omitted variables bias. First, we examined fourteen different additive models ranging from including two explanatory variables at once to all six variables entered together. Although there existed some significant correlations between explanatory variables as reported in Table 1, they did not cause serious collinearity problems in additive models as measured by variance inflation factor (VIF) scores of explanatory variables and regression models.

We find in columns of 8 to 14 of Tables 2 and 3 that the test results are consistent across different additive models of selectivity and conviction, except the coefficients of formal business planning, which are not significant in additive models of conviction. Unlike consistently positive and significant relationship between formal business planning and selectivity, the relationship between formal business plan and conviction is getting weaker when entered with other explanatory variables.

As multiplicative models, we investigated potential non-linear forms or complementary (or substitutive) relationships between the explanatory variables and find a positive interaction effect of task uncertainty and entrepreneurial decisiveness on selectivity in which the conditional effect 
of task uncertainty on selectivity is negative and significant. In contrast, we find a negative interaction effect of task uncertainty and entrepreneurial decisiveness on conviction where the conditional effects of task uncertainty and entrepreneurial decisiveness on conviction remain positive and significant.

Figure 2 presents plots of the marginal effects of venture-specific experience and entrepreneurial uncertainty based on the results in Tables 2 and 3. The marginal effects of experience variables (i.e., time spent in the venture and formal business planning) and uncertainty variables (i.e., task uncertainty and customer uncertainty) are calculated with all other variables held at their means. As hypothesized, we find positive effects of the two experience variables on selectivity of entrepreneurial judgment as shown in the overall positive slopes of the lines. Similarly, we find negative effects of the uncertainty variables on selectivity in a decreasing slope, and negative effects on conviction in an increasing slope.

\section{Figure 2}

The marginal effect analysis extends our insights by exploring how different variables of venture-specific experience and entrepreneurial uncertainty affect selectivity and conviction, respectively. First, we find that formal business planning has a complementary effect on selectivity in early (less than 100 hours spent in the venture) and later (more than 1800 hours) stages of venture development. In contrast, their complementary effect on conviction is found mostly in-between (100 to 600 hours). Second, we find that the negative effect of task uncertainty on selectivity is strengthened with customer uncertainty, but their complementary effect disappears when task uncertainty is very high (i.e., the new business is originated from other people's research or idea, not from the entrepreneur's current or previous work). Finally, 
we find a consistent and complementary effect of task and customer uncertainty variables on conviction regardless of different origins of new ventures.

\section{DISCUSSION}

This study contributes to entrepreneurship research by developing a cognitive model of entrepreneurial judgment as reflected in the shape and strength of the entrepreneur's causal map. The results of empirical analysis demonstrate how entrepreneurial judgment evolves after the initial epiphany as the entrepreneur accumulates experience in the venturing process. In the face of uncertainty, the entrepreneur's venture-specific experience and cognitive dispositions, along with customer uncertainty influence selectivity and conviction in entrepreneurial judgment. Implications for research

First, we investigated the selectivity of entrepreneurial judgment as it relates to the key success factors of that particular venture. We conceptualized entrepreneurial judgment as a cognitive process operating on a causal map entrepreneurs construct regarding the success of their ventures. We find as entrepreneurs invest more time working for their ventures, their causal maps become more refined. Out of the ten factors that the entrepreneurs assess in our empirical study, they settle down on fewer important predictors of success as they spend more time on their ventures. Their experience leads to the elimination of alternative theories for the successful venture. Similarly, the effort they spend on writing a formal business plan makes their judgment more selective as well. The results indicate that those entrepreneurs who prepared formal business plans have more refined causal maps than those who did not. Taken together, these findings support the entrepreneurial learning literature as they demonstrate how time and effort spent for the venture transform the cognition of the entrepreneurs (Holcomb et al., 2009). As experiential learning theory suggests, for learning to occur there has to be a change in ideas and 
habits (Kolb, 1984). This study demonstrates how that change in entrepreneurial judgment occurs at a hard-to-measure cognitive level. In general, we posit that the knowledge structure in the mind of the entrepreneur shapes the exercise of judgment during the entrepreneurial process (Ardichvili et al., 2003; Corbett and Hmieleski, 2007).

We proposed that venture uncertainty and the cognitive dispositions of the entrepreneurs would influence entrepreneurial judgment as well. Our findings about uncertainty provide only partial support of our theory. We did not find that the entrepreneurs had difficulty in identifying the key success factors in an opportunity defined by high uncertainty. An explanation is that our uncertainty measures do not capture Knightian uncertainty as intended by our model fully. Alternatively, we conjecture entrepreneurs make selective judgments because they resort to effectuation strategies in highly uncertain ventures (Sarasvathy, 2001).

In terms of cognitive disposition, we find that individuals who identify themselves as decisive are more likely to have selective judgments. We interpret that finding by referring to their comfort level in making decisions under uncertainty. When taken collectively, these determinants of a refined causal map have implications for broader theory of entrepreneurial judgment and cognition. When defined as resource allocation or exploitation decisions, entrepreneurial judgment relates very strongly to the knowledge structures we examine in this study. This is a novel contribution to the entrepreneurial judgment perspective since our empirical study opens the cognitive black box of judgment in the mind of the entrepreneur (Sarasvathy and Dew, 2013). As the entrepreneur identifies a smaller set of factors that will lead to profitability, we would expect her resource allocation decisions to follow suit. She will be in a better position to make investment decisions as her causal map becomes more focused. 
The second aspect of entrepreneurial judgment we investigated is the entrepreneur's conviction in her judgment. Having an opinion about the key success factors is different from the strength of that opinion. Consistent with our theoretical approach to experiential learning, we find that spending more time with the venture strengthens the entrepreneur's conviction in judgment. Similarly, preparing a formal business plan makes her conviction stronger as well. That conviction is important because when the entrepreneur firmly believes in the plausibility of a success factor, she is more likely to invest resources in that direction (Minniti and Bygrave, 2001). At a cognitive level this is made possible by alleviating doubt that would otherwise hinder entrepreneurial actions (McMullen and Shepherd, 2006).

In our sample of nascent entrepreneurs, we find that uncertainty has mixed effects on conviction. Task uncertainty, which we postulated to increase the entrepreneur's conviction, has no significant effect. However, when the product is unknown to the customers we find that the entrepreneurs have stronger conviction in their judgments. This finding is particularly interesting given that those two constructs represent opportunity uncertainty from two different viewpoints. Task uncertainty is what the entrepreneur faces in the new venture provided her prior work experience and knowledge base. Given the distance between the prior knowledge and the new venture tasks, they may decide they need to learn the new business and engage in further search behavior. This in turn will lead to doubt, rather than conviction, in their causal maps.

In contrast, novel and unknown product is what the customer will be facing in the market. This finding is consistent with the previous findings of optimism (Cassar, 2010). When the product is a novel one the entrepreneurs are more strongly opinionated about their own judgments. In those situations of high customer uncertainty, the entrepreneurs will rely on cognitive heuristics and interpret the customer's uncertainty as a sign of the product's novelty in 
their judgment. When the product is truly novel and the entrepreneur believes that the uncertainty will present unknowns to others as well (i.e., unknowable unknowns), this creates a more comfortable cognitive state for the entrepreneur (Chow and Sarin, 2002). As such, customer uncertainty can reinforce the entrepreneur’s conviction in her judgment.

Finally, we find strong support for our hypotheses on cognitive dispositions and conviction. Entrepreneurs who report higher levels of self-efficacy and decisiveness also show higher levels of conviction. According to the theoretical model by Minniti and Bygrave (2001) a positive outcome early in the process may lock in the dynamics, sometimes prematurely. Our finding about entrepreneurial self-efficacy and conviction can be the underlying cognitive mechanism. It is important to underline that the observed correlations between the cognitive dispositions and the conviction in judgment are not driven by a common method bias in self-reported data. That could be the case if our conviction measure were simply a direct question of confidence in the venture's success. In fact, independently from those measures, we operationalize conviction using a completely separate set of the PSED II items. Conviction in entrepreneurial judgment is a pure cognitive measure without any common emotional component driving a spurious correlation. Therefore, our finding must be interpreted as a form of cognitive commitment in contrast to an emotional state. We find that such cognitive commitment is highly correlated with entrepreneurial self-efficacy and decisiveness of the entrepreneur.

Implications for entrepreneurs, educators, and investors

For entrepreneurs it is important to understand the cognitive mechanisms underpinning the judgments they make. Our findings suggest that their decision patterns can be partially understood and predicted based on their experience with the venture and cognitive dispositions. Entrepreneurs learn in different ways (Corbett, 2005). To the extent that the refinement in 
judgment is useful, the entrepreneurs are advised to increase the range of start-up activities (cf. Gielnik et al., 2012). Furthermore, the significant roles of entrepreneurial self-efficacy and decisiveness may imply a precarious scenario. When the entrepreneurs are formulating a strategy to guide their resource allocation decisions, these cognitive attributes may help them in narrowing down important options for attention. However, their strong effect on conviction may also suggest that there is a risk of over-optimism or over-confidence in their judgments regardless of the accuracy of their judgments. Further research is necessary to delineate the performance implications of entrepreneurial judgment ex post.

This study also provides important implications for those who assess the entrepreneurs' judgments. Investors and venture capitalists need to examine the accuracy of the entrepreneurs' judgments and their underlying knowledge structures about the critical success factors. The impact of self-efficacy and decisiveness on conviction can be a warning sign for the entrepreneurs' ungrounded judgments. Our findings imply that investors are advised to explore the sources of cognitive commitment by the entrepreneur and check if the conviction is supported by accumulated experience in the specific context of the venture.

For entrepreneurship education, our findings may be referred to show the reality of entrepreneurship in practice as nascent entrepreneurs often have to exercise judgment with limited information. When entrepreneurship is seen as novel resource combinations under scarcity and uncertainty, the selectivity of entrepreneurial judgment matters. It seems that practicing entrepreneurs are aware that they cannot effectively make progress in all aspects of a new venture at once. As they get more experienced with the venture, they choose the more important success factors to focus on. Students of entrepreneurship would benefit from knowing that learning is context specific and entrepreneurial judgment evolves in the venturing process. 


\section{Boundary conditions and future research}

It is important to understand the boundary conditions of our findings as they also provide ideas for extension and future research. First, inferences about the observed relationships should be made with caution as the study used the PSED II data only up to the Wave A survey. In the follow-up surveys, there are sample selection issues due to venture disbanding decision and various filtering used in the PSED II survey such as becoming a profitable business. As such, a dynamic modeling approach is recommended in future research.

Second, because our focus is on the evolution of entrepreneurial judgment, we do not investigate its effect on entrepreneurial action or venture performance (cf. Baron and Henry, 2010). However, the intensity of entrepreneurs' efforts in experiential learning and knowledge acquisition may be influenced by their intended goals and expected outcomes. Although we include several control variables in estimation to rule out possible endogeneity issues, it is clear that examining actions and goals on outcomes in a systematic manner is a natural extension.

Third, our sample entrepreneurs were in venture development for about 18 months on average at the time they participated in the first PSED II survey. Respondents' perceived uncertainty and their cognitive disposition may persist through time, but they may be affected by the changing circumstances in later stage of venture progress. With respect to the PSED II sampling, we also have to note that we focused on nascent entrepreneurs who had the general intention to start a new business. Thus, our findings might only be generalizable to this group of individuals sharing such entrepreneurial intention and background. Furthermore, it is also likely that our findings can only be generalized to a particular phase of the entrepreneurial process in which the entrepreneurs have already acquired some level of knowledge to form their intention and start a new business. This might reduce the variance in our measures of the evolution of 
entrepreneurial judgment, which, in turn, might weaken the effect size and statistical significance of the empirical results. Nonetheless, we find that most of our results are statistically significant.

Future research can extend our causal map model and application of cognitive mechanisms on the entrepreneurial judgment theories. One way forward might be to compare entrepreneurial judgment with analytical decision-making situations such as location or funding decisions based on verifiable information. They are likely to be associated with different entrepreneurial attributes, cognitive characteristics, decision-making capabilities, and experience bases. In our empirical analysis, we found some interesting patterns involving college education and growth intention as shown in Table 1. Notably, however, we find that general (founding and managerial) experience variables are not significant in their relationship with entrepreneurial judgment.

Upon imagining a new venture organization, the entrepreneur has to make resource allocation decisions in order to exploit the opportunity she perceives. We propose that the causal map is the knowledge structure in her mind that guides these difficult decisions. For example, when the entrepreneur believes that price is more important than marketing for profitability of her venture, she is more likely to invest resources that will reduce operating costs than increase advertising expenses. While the causal map serves as a guide, however, it is not a snapshot of resource allocation decisions as imagined by Foss and Klein (2012). The causal map developed in this study is a precursor to the actual resource allocations. Further empirical research is needed to bridge the gap between cognitive constructs and financial investments as hinted by Knight (Knight, 1921) a century ago.

\section{CONCLUSION}

The theory and evidence presented in this research contributes to the entrepreneurship literature in several ways. First, we develop a conceptual model of entrepreneurial judgment operating on 
the causal map and examine how this important knowledge structure in the mind of the entrepreneur evolves with experience in the context of the new venture. According to the model, venture-specific experience, as opposed to general industry experience or human capital, can make a difference in the way entrepreneurs make decisions under uncertainty. We report considerable empirical support of the causal map model using a representative sample of nascent entrepreneurs. Second, we advance the construct of entrepreneurial judgment both theoretically and empirically. Most of the literature on the evolution of venture-specific knowledge and judgment is theoretical (e.g. Cope, 2005; Corbett, 2005; Foss and Klein, 2012; Holcomb et al., 2009; Klein, 2008; Minniti and Bygrave, 2001). We draw on a publicly available dataset and provide a first attempt at operationalizing entrepreneurial judgment in terms of selectivity and conviction using entrepreneurs' subjective assessments of a set of success factors in the venture. We hope that future research will build on our cognitive approach to entrepreneurial judgment in the mind of the entrepreneur. 


\section{References}

Allinson CW, Chell E, Hayes J. 2000. Intuition and entrepreneurial behaviour. European Journal of Work and Organizational Psychology 9(1):31-43.

Alvarez SA, Barney JB. 2007. Discovery and creation: alternative theories of entrepreneurial action. Strategic Entrepreneurship Journal 1(1-2):11-26.

Ardichvili A, Cardozo R, Ray S. 2003. A theory of entrepreneurial opportunity identification and development. Journal of Business Venturing 18(1):105-123.

Bandura A. 1986. The explanatory and predictive scope of self-efficacy theory. Journal of Social and Clinical Psychology 4(3):359-373.

Baron RA, Ensley MD. 2006. Opportunity recognition as the detection of meaningful patterns: Evidence from comparisons of novice and experienced entrepreneurs. Management Science 52(9):1331-1344.

Baron RA, Henry RA. 2010. How entrepreneurs acquire the capacity to excel: insights from research on expert performance. Strategic Entrepreneurship Journal 4(1):49-65.

Batstone S, Pheby J. 1996. Entrepreneurship and decision making: the contribution of GLS Shackle. International Journal of Entrepreneurial Behavior \& Research 2(2):34-51.

Brinckmann J, Grichnik D, Kapsa D. 2010. Should entrepreneurs plan or just storm the castle? A meta-analysis on contextual factors impacting the business planning-performance relationship in small firms. Journal of Business Venturing 25(1):24-40.

Brinckmann J, Kim SM. 2015. Why We Plan: The Impact of Nascent Entrepreneurs' Cognitive Characteristics and Human Capital on Business Planning. Strategic Entrepreneurship Journal 9(2):153-166.

Brüderl J, Preisendörfer P, Ziegler R. 1992. Survival chances of newly founded business organizations. American sociological review 57:227-242.

Burton R. 2009. On being certain: Believing you are right even when you're not. St. Martin's Griffin: New York.

Cassar G. 2006. Entrepreneur opportunity costs and intended venture growth. Journal of Business Venturing 21(5):610-632.

Cassar G. 2010. Are individuals entering self-employment overly optimistic? An empirical test of plans and projections on nascent entrepreneur expectations. Strategic Management Journal 31(8):822-840. 
Cassar G, Friedman H. 2009. Does self-efficacy affect entrepreneurial investment? Strategic Entrepreneurship Journal 3(3):241-260.

Casson M. 1982. The entrepreneur : an economic theory. M. Robertson: Oxford Eng.

Castrogiovanni GJ. 1996. Pre-startup planning and the survival of new small businesses: Theoretical linkages. Journal of Management 22(6):801-822.

Chow CC, Sarin RK. 2002. Known, unknown, and unknowable uncertainties. Theory and Decision 52(2):127-138.

Cooper AC, Folta TB, Woo C. 1995. Entrepreneurial information search. Journal of Business Venturing 10(2):107-120.

Cope J. 2005. Toward a dynamic learning perspective of entrepreneurship. Entrepreneurship: Theory \& Practice 29(4):373-397.

Corbett AC. 2002. Recognizing high-tech opportunities: A learning and cognitive approach. Frontiers of Entrepreneurship Research(Journal Article):49-60.

Corbett AC. 2005. Experiential learning within the process of opportunity identification and exploitation. Entrepreneurship Theory \& Practice 29(4):473-491.

Corbett AC, Hmieleski KM. 2007. The conflicting cognitions of corporate entrepreneurs. Entrepreneurship Theory and Practice 31(1):103-121.

Dahlqvist J, Wiklund J. 2012. Measuring the market newness of new ventures. Journal of Business Venturing 27(2):185-196.

Davidson R, MacKinnon JG. 1993. Estimation and inference in econometrics. OUP Catalogue.

Delmar F, Shane S. 2003. Does business planning facilitate the development of new ventures? Strategic Management Journal 24(12):1165-1185.

Delmar F, Shane S. 2006. Does experience matter? The effect of founding team experience on the survival and sales of newly founded ventures. Strategic Organization 4(3):215-247.

Dimov D. 2007. Beyond the single-person, single-insight attribution in understanding entrepreneurial opportunities. Entrepreneurship Theory and Practice 31(5):713-731.

Dimov D. 2010. Nascent entrepreneurs and venture emergence: Opportunity confidence, human capital, and early planning. Journal of Management Studies 47(6):1123-1153.

Dokko G, Wilk SL, Rothbard NP. 2009. Unpacking prior experience: How career history affects job performance. Organization Science 20(1):51-68. 
Dougherty MR, Harbison J. 2007. Motivated to retrieve: How often are you willing to go back to the well when the well is dry? Journal of Experimental Psychology: Learning, Memory, and Cognition 33(6):1108-1117.

Drnovšek M, Wincent J, Cardon MS. 2010. Entrepreneurial self-efficacy and business start-up: developing a multi-dimensional definition. International Journal of Entrepreneurial Behaviour \& Research 16(4):329-348.

Eckhardt JT, Shane SA. 2003. Opportunities and entrepreneurship. Journal of Management 29(3):333-349.

Ellsberg D. 1961. Risk, ambiguity, and the Savage axioms. The quarterly journal of economics:643-669.

Forbes DP. 2007. Reconsidering the strategic implications of decision comprehensiveness. Academy of Management Review 32(2):361-376.

Foss NJ, Klein PG. 2008. Entrepreneurship: From Opportunity Discovery to Judgment. SSRN.

Foss NJ, Klein PG. 2012. Organizing entrepreneurial judgment: a new approach to the firm. Cambridge University Press: Cambridge, UK.

Gielnik MM, Frese M, Graf JM, Kampschulte A. 2012. Creativity in the opportunity identification process and the moderating effect of diversity of information. Journal of Business Venturing 27(5):559-576.

Gopnik A, Glymour C. 2002. Causal maps and Bayes nets: A cognitive and computational account of theory-formation. The cognitive basis of science:117-132.

Grégoire DA, Barr PS, Shepherd DA. 2010. Cognitive processes of opportunity recognition: The role of structural alignment. Organization Science 21(2):413-431.

Grégoire DA, Corbett AC, McMullen JS. 2011. The cognitive perspective in entrepreneurship: An agenda for future research. Journal of Management Studies 48(6):1443-1477.

Grégoire DA, Shepherd DA. 2012. Technology-market combinations and the identification of entrepreneurial opportunities: An investigation of the opportunity-individual nexus. Academy of Management Journal 55(4):753-785.

Haynie JM, Shepherd DA, Patzelt H. 2012. Cognitive adaptability and an entrepreneurial task: The role of metacognitive ability and feedback. Entrepreneurship Theory \& Practice 36(2):237265.

Holcomb TR, Ireland RD, Holmes RM, Hitt MA. 2009. Architecture of entrepreneurial learning: Exploring the link among heuristics, knowledge, and action. Entrepreneurship Theory and Practice 33(1):167-192. 
Huckman RS, Pisano GP. 2006. The firm specificity of individual performance: Evidence from cardiac surgery. Management Science 52(4):473-488.

Kitchin RM. 1994. Cognitive maps: What are they and why study them? Journal of Environmental Psychology 14(1):1-19.

Klein PG. 2008. Opportunity discovery, entrepreneurial action, and economic organization. Strategic Entrepreneurship Journal 2(3):175-190.

Knight FH. 1921. Risk, uncertainty and profit. In Harper Torchbooks. The Academy library, TB 1215P. Harper \& Row, 1965: New York, NY; lxiv, 381-lxiv, 381.

Kolb DA. 1984. Experiential learning: Experience as the source of learning and development. Prentice Hall: Englewood Cliffs, NJ.

Kruglanski AW. 1989. Lay epistemics and human knowledge: Cognitive and motivational bases. Plenum Press: New York.

Kruglanski AW, Webster DM. 1996. Motivated closing of the mind:" Seizing" and" freezing". Psychological review 103(2):263-283.

Langlois RN. 2007. The entrepreneurial theory of the firm and the theory of the entrepreneurial firm. Journal of Management Studies 44(6):1107-1124.

Leaptrott J, McDonald JM. 2008. Looking before leaping: The effect of owner decisiveness on small business performance. Academy of Entrepreneurship Journal 14(1):41-53.

Mahoney JT, Michael SC. 2005. A subjectivist theory of entrepreneurship. In Handbook of Entrepreneurship Research: Interdisciplinary Perspectives, Alvarez SA, Agarwal R, Sorenson O (eds). Springer: New York, NY; 33-55.

McMullen JS, Shepherd DA. 2006. Entrepreneurial action and the role of uncertainty in the theory of the entrepreneur. Academy of Management Review 31(1):132-152.

Messick S. 1976. Individuality in learning. Jossey-Bass Publishers: San Francisco, CA.

Michael SC. 2007. Entrepreneurship, growth, and Adam Smith. Strategic Entrepreneurship Journal 1(3-4):287-289.

Minniti M, Bygrave W. 2001. A dynamic model of entrepreneurial learning. Entrepreneurship Theory \& Practice 25(3):5-14.

Mintzberg H. 1991. Learning 1, planning 0: Reply to Igor Ansoff. Strategic Management Journal 12(6):463-466. 
Mitchell RK, Busenitz L, Lant T, McDougall PP, Morse EA, Smith JB. 2002a. Toward a theory of entrepreneurial cognition: Rethinking the people side of entrepreneurship research.

Entrepreneurship: Theory \& Practice 27(2):93-104.

Mitchell RK, Busenitz LW, Bird B, Gaglio CM, McMullen JS, Morse EA, Smith JB. 2007. The central question in entrepreneurial cognition research 2007. Entrepreneurship Theory and Practice 31(1):1-27.

Mitchell RK, Smith B, Seawright KW, Morse EA. 2000. Cross-cultural cognitions and the venture creation decision. Academy of Management Journal 43(5):974-993.

Mitchell RK, Smith JB, Morse EA, Seawright KW, Peredo AM, McKenzie B. 2002b. Are entrepreneurial cognitions universal? Assessing entrepreneurial cognitions across cultures. Entrepreneurship Theory \& Practice 26(4):9-32.

Nadkarni S, Shenoy PP. 2001. A Bayesian network approach to making inferences in causal maps. European Journal of Operational Research 128(3):479-498.

Naldi L, Davidsson P. 2013. Entrepreneurial growth: The role of international knowledge acquisition as moderated by firm age. Journal of Business Venturing(0).

Neuberg SL, Judice TN, West SG. 1997. What the Need for Closure Scale measures and what it does not: Toward differentiating among related epistemic motives. Journal of personality and social psychology 72(6):1396-1412.

Newbert SL, Tornikoski ET, Quigley NR. 2012. Exploring the evolution of supporter networks in the creation of new organizations. Journal of Business Venturing.

Powell GN, Eddleston KA. 2013. Linking family-to-business enrichment and support to entrepreneurial success: Do female and male entrepreneurs experience different outcomes? Journal of Business Venturing 28(2):261-280.

Regnér P. 2003. Strategy creation in the periphery: Inductive versus deductive strategy making. Journal of Management Studies 40(1):57-82.

Reynolds PD, Curtin RT. 2008. Business creation in the United States: Panel Study of Entrepreneurial Dynamics II initial assessment. Foundations and Trends in Entrepreneurship 4(3):155-307.

Sapienza HJ, Gupta AK. 1994. Impact of agency risks and task uncertainty on venture capitalistCEO interaction. Academy of Management Journal 37(6):1618-1632.

Sarasvathy SD. 2001. Causation and Effectuation: Toward a Theoretical Shift from Economic Inevitability to Entrepreneurial Contingency. Academy of Management Review 26(2):243-263. 
Sarasvathy SD, Dew N. 2013. Without judgment: An empirically-based entrepreneurial theory of the firm. The Review of Austrian economics 26(3):277-296.

Schumpeter JA. 1934. The theory of economic development: An inquiry into profits, capital, credit, interest, and the business cycle. Harvard University Press: Cambridge, MA.

Schwarz N, Vaughn LA. 2002. The availability heuristic revisited: Ease of recall and content of recall as distinct sources of information. In Heuristics and biases: The psychology of intuitive judgment, Gilovich T. GD, Kahneman D. (ed). Cambridge University Press: Cambridge, UK; 103-119.

Shackle G. 1970. Expectation, Enterprise and Profit. London: Allen and Unwin.

Stock J. 2001. Instrumental variables in statistics and econometrics. In In International Encyclopaedia of the Behavioural Sciences, Smelser NBP (ed). Elsevier Publishing: New York; 7577-7582.

Thagard P. 1992. Conceptual revolutions. Princeton University Press: Princeton, N.J.

Toft-Kehler R, Wennberg K, Kim PH. 2013. Practice makes perfect: Entrepreneurial-experience curves and venture performance. Journal of Business Venturing.

Tolman EC. 1948. Cognitive maps in rats and men. Psychological review(55):189-208.

Townsend DM, Busenitz LW, Arthurs JD. 2010. To start or not to start: Outcome and ability expectations in the decision to start a new venture. Journal of Business Venturing 25(2):192-202.

Trevelyan R. 2011. Self-efficacy and effort in new venture development. Journal of Management \& Organization 17(1):2-16.

Tversky A, Kahneman D. 1973. Availability: A heuristic for judging frequency and probability. Cognitive psychology 5(2):207-232.

Tversky A, Kahneman D. 1974. Judgment under uncertainty: Heuristics and biases. Science 185(4157):1124-1131.

Uy MA, Foo M-D, Song Z. 2012. Joint effects of prior start-up experience and coping strategies on entrepreneurs' psychological well-being. Journal of Business Venturing.

Uygur U. 2016. An Analogy Explanation for the Evaluation of Entrepreneurial Opportunities. Journal of Small Business Management forthcoming.

Ward TB. 2004. Cognition, creativity, and entrepreneurship. Journal of Business Venturing 19(2):173-188. 
Weick KE, Roberts KH. 1993. Collective mind in organizations: Heedful interrelating on flight decks. Administrative Science Quarterly 38:357-381.

Westhead P, Ucbasaran D, Wright M. 2005. Decisions, actions, and performance: Do novice, serial, and portfolio entrepreneurs differ? Journal of Small Business Management 43(4):393-417.

Yang T, Aldrich HE. 2012. Out of sight but not out of mind: Why failure to account for left truncation biases research on failure rates. Journal of Business Venturing 27(4):477-492.

Yli-Renko H, Autio E, Sapienza HJ. 2001. Social capital, knowledge acquisition, and knowledge exploitation in young technology-based firms. Strategic Management Journal 22(6-7):587-613.

Zahra SA, Ireland RD, Hitt MA. 2000. International expansion by new venture firms:

International diversity, mode of market entry, technological learning, and performance. Academy of Management Journal 43(5):925-950. 


\section{PSED II Section F: Attitude toward competition}

Please indicate whether you strongly agree, agree, neither agree nor disagree, disagree or strongly disagree with each of the following statements as it applies to this new business. are important for this new business to be an effective competitor.

\begin{tabular}{lllrr}
\hline PSED II & Variables & Survey Questions & MEAN & STDEV \\
\hline AF1 & Price & Lower prices & 2.99 & 1.78 \\
AF2 & Quality & Quality products or services & 1.44 & 1.06 \\
AF3 & Niche & Serving those missed by others. & 2.03 & 1.49 \\
AF4 & Timing & Being first to market a new product or service & 3.08 & 1.85 \\
AF5 & Marketing & Doing a better job of marketing and promotion & 1.97 & 1.29 \\
AF6 & Access & A superior location and customer convenience & 2.85 & 1.83 \\
AF7 & Design & More contemporary, attractive products & 2.93 & 1.88 \\
AF8 & Know-how & The technical and scientific expertise of the start-up team & 2.86 & 1.88 \\
AF9 & Innovation & $\begin{array}{l}\text { Developing new or advanced product technology or } \\
\text { process technology for creating goods or services }\end{array}$ & 3.36 & 1.95 \\
AF10 & IP & $\begin{array}{l}\text { Development of intellectual property such as a patent, } \\
\text { copyright or trademark }\end{array}$ & 3.90 & 1.93 \\
\hline
\end{tabular}

\begin{tabular}{ccccccccccccc}
\hline \multicolumn{1}{l}{ Ind. Price } & Quality & Niche & Timing & Marketing & Access & Design & Know-how & Innovation & IP & Selectivity & Conviction \\
\hline A & 3 & 3 & 3 & 3 & 3 & 3 & 3 & 3 & 3 & 3 & 0 & 0 \\
B & 5 & 5 & 5 & 5 & 5 & 5 & 5 & 5 & 5 & 5 & 0 & 20 \\
C & 4 & 2 & 4 & 5 & 4 & 4 & 5 & 4 & 5 & 4 & 0.21 & 13 \\
D & 1 & 1 & 1 & 4 & 2 & 5 & 1 & 1 & 2 & 5 & 0.74 & 17 \\
\hline
\end{tabular}

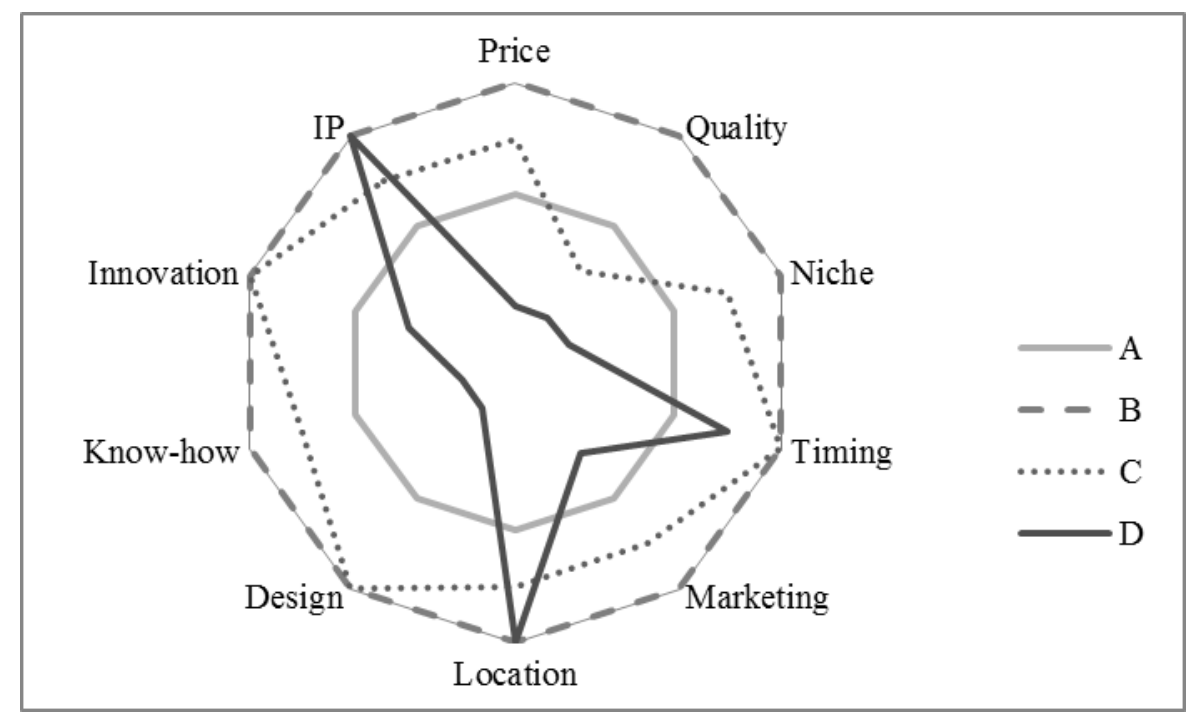

Figure 1. Illustrations of the Dependent Variables 

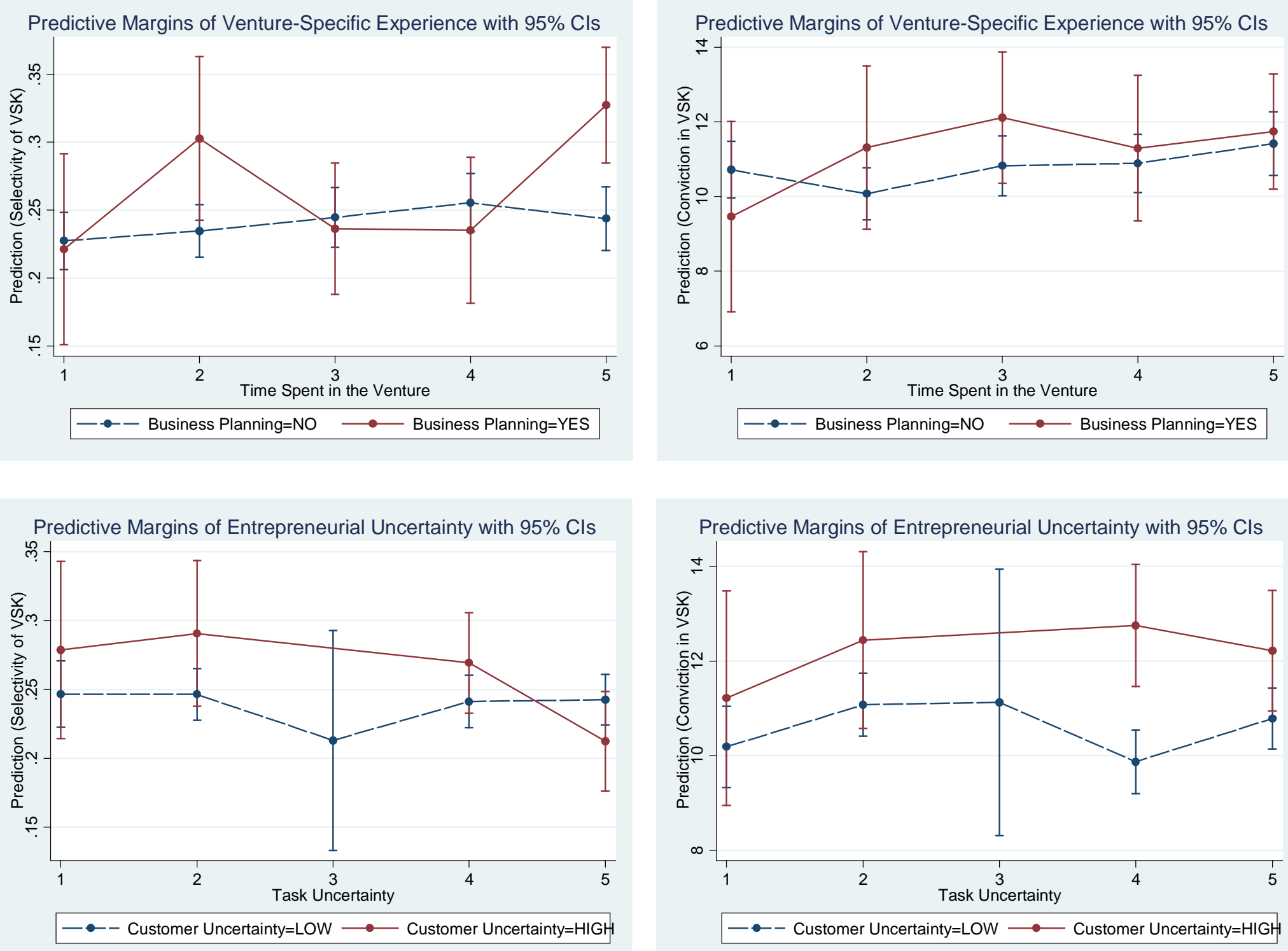

Predictive Margins of Entrepreneurial Uncertainty with 95\% Cls

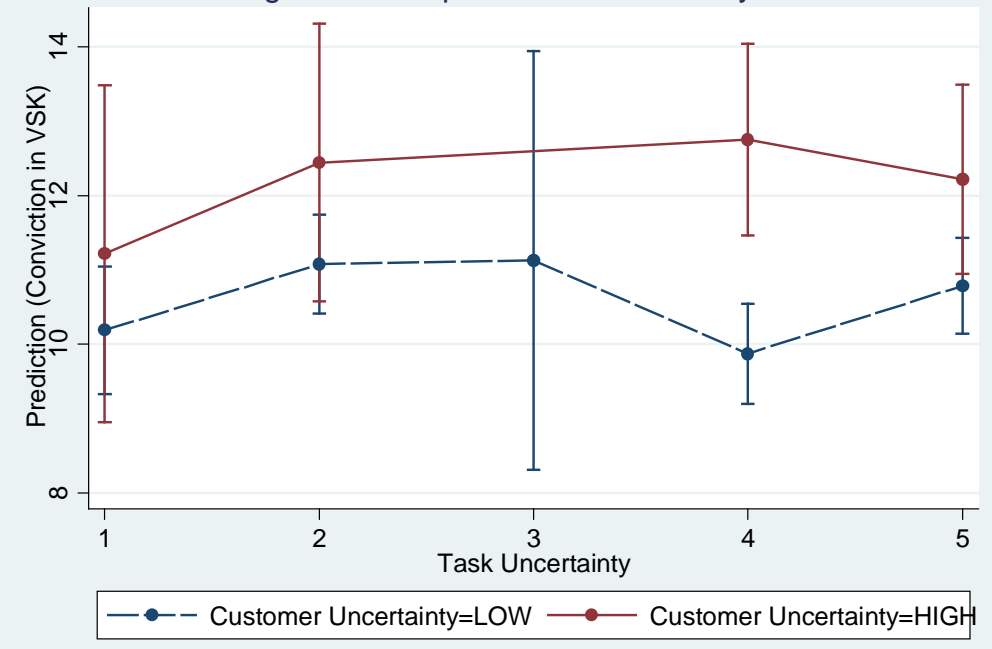

Figure 2. Marginal effects of experience and uncertainty on entrepreneurial judgment 
Table 1. Descriptive statistics and correlation matrix

\begin{tabular}{|c|c|c|c|c|c|c|c|c|c|c|c|c|c|c|c|c|c|c|c|c|c|c|c|c|c|}
\hline & Variables & 1 & 2 & 3 & 4 & 5 & 6 & 7 & 8 & 9 & 10 & 11 & 12 & 13 & 14 & 15 & 16 & 17 & 18 & 19 & 20 & 21 & 22 & 23 & 24 \\
\hline 1 & Selectivity of ent. judgment & 1.00 & & & & & & & & & & & & & & & & & & & & & & & \\
\hline 2 & Conviction in ent. judgment & 0.04 & 1.00 & & & & & & & & & & & & & & & & & & & & & & \\
\hline 3 & Time Spent (log) & 0.14 & 0.09 & 1.00 & & & & & & & & & & & & & & & & & & & & & \\
\hline 4 & Formal Business Plan & 0.10 & 0.08 & 0.15 & 1.00 & & & & & & & & & & & & & & & & & & & & \\
\hline 5 & Task Uncertainty & -0.07 & $0.02-$ & -0.08 & -0.03 & 1.00 & & & & & & & & & & & & & & & & & & & \\
\hline 6 & Customer Uncertainty & 0.00 & 0.20 & 0.01 & 0.07 & 0.12 & 1.00 & & & & & & & & & & & & & & & & & & \\
\hline 7 & Self-Efficacy & -0.07 & 0.19 & 0.07 & 0.07 & -0.14 & 0.01 & 1.00 & & & & & & & & & & & & & & & & & \\
\hline 8 & Decisiveness & 0.12 & 0.11 & 0.04 & 0.16 & $-0.08-$ & -0.09 & 0.05 & 1.00 & & & & & & & & & & & & & & & & \\
\hline 9 & Founding Experience & 0.07 & 0.02 & 0.04 & 0.00 & -0.03 & 0.04 & -0.05 & 0.05 & 1.00 & & & & & & & & & & & & & & & \\
\hline 10 & Managerial Experience & 0.10 & 0.01 & 0.10 & $-0.02-$ & $-0.08-$ & -0.10 & 0.02 & 0.20 & 0.23 & 1.00 & & & & & & & & & & & & & & \\
\hline 11 & Business Portfolio & 0.04 & -0.06 & 0.01 & $-0.03-$ & -0.02 & 0.05 & -0.08 & 0.07 & 0.63 & 0.09 & 1.00 & & & & & & & & & & & & & \\
\hline 12 & Employed Full-time & 0.05 & 0.03 & 0.11 & 0.06 & $-0.05-$ & -0.05 & 0.06 & 0.03 & 0.07 & 0.02 & 0.13 & 1.00 & & & & & & & & & & & & \\
\hline 13 & College Education & 0.14 & 0.02 & 0.08 & 0.16 & -0.09 & 0.00 & -0.11 & 0.14 & 0.06 & 0.20 & 0.07 & 0.06 & 1.00 & & & & & & & & & & & \\
\hline 14 & Married & 0.03 & $-0.08-$ & -0.05 & 0.00 & $-0.11-$ & -0.03 & -0.02 & $0.08-$ & -0.01 & 0.06 & 0.01 & 0.02 & 0.01 & 1.00 & & & & & & & & & & \\
\hline 15 & Female & -0.04 & $-0.01-$ & -0.06 & -0.03 & $0.07-$ & -0.08 & -0.07 & $-0.02-$ & -0.04 & -0.06 & 0.01 & -0.13 & 0.07 & 0.09 & 1.00 & & & & & & & & & \\
\hline 16 & Opportunity Expectancy (log) & -0.08 & 0.13 & 0.07 & 0.08 & 0.01 & 0.05 & 0.01 & 0.00 & 0.02 & $0.00-$ & -0.02 & $0.03-$ & $-0.01-$ & $-0.11-$ & -0.19 & 1.00 & & & & & & & & \\
\hline 17 & Growth Intention & -0.11 & 0.18 & 0.01 & 0.09 & 0.02 & 0.16 & 0.06 & 0.08 & 0.11 & -0.05 & 0.08 & 0.04 & $0.04-$ & -0.06 & -0.11 & 0.26 & 1.00 & & & & & & & \\
\hline 18 & Local Customers(\%) & -0.03 & $-0.04-$ & -0.11 & $-0.03-$ & $-0.01-$ & -0.11 & $-0.01-$ & $-0.07-$ & -0.11 & $-0.08-$ & -0.12 & $0.00-$ & -0.13 & 0.02 & $0.12-$ & $-0.09-$ & -0.09 & 1.00 & & & & & & \\
\hline 19 & International Customers(\%) & -0.04 & 0.05 & 0.01 & 0.07 & 0.03 & 0.10 & $-0.01-$ & -0.03 & 0.05 & -0.05 & 0.05 & -0.06 & $0.04-$ & -0.09 & -0.09 & 0.13 & 0.16 & -0.36 & 1.00 & & & & & \\
\hline 20 & Founding Environment & 0.10 & -0.18 & 0.03 & 0.01 & 0.06 & 0.02 & -0.10 & $-0.03-$ & -0.07 & -0.13 & 0.05 & 0.12 & $-0.05-$ & -0.02 & $-0.03-$ & -0.10 & 0.00 & $0.05-$ & -0.11 & 1.00 & & & & \\
\hline 21 & External Funding & -0.07 & -0.04 & 0.13 & 0.11 & $-0.01-$ & -0.02 & 0.05 & 0.04 & 0.02 & 0.00 & 0.03 & 0.18 & 0.04 & 0.02 & $-0.04-$ & -0.04 & 0.07 & 0.00 & $0.04-$ & -0.01 & 1.00 & & & \\
\hline 22 & Development Phase & 0.10 & -0.02 & 0.27 & $-0.01-$ & $-0.11-$ & -0.07 & -0.10 & 0.00 & 0.07 & 0.09 & -0.01 & 0.05 & 0.06 & 0.11 & $0.06-$ & $-0.10-$ & -0.04 & $-0.01-$ & $-0.08-$ & -0.01 & 0.05 & 1.00 & & \\
\hline 23 & R\&D Intensity & -0.15 & 0.16 & 0.06 & 0.01 & -0.03 & 0.10 & 0.10 & -0.10 & -0.07 & -0.13 & -0.08 & $0.03-$ & $-0.08-$ & -0.08 & -0.04 & 0.14 & 0.07 & -0.02 & $0.02-$ & -0.02 & $0.00-($ & -0.06 & 1.00 & \\
\hline 24 & Industry SIC & 0.03 & 0.03 & 0.01 & 0.06 & $0.02-$ & -0.06 & 0.00 & 0.00 & 0.02 & $-0.03-$ & -0.02 & -0.05 & $0.03-$ & -0.05 & $0.04-$ & $-0.10-$ & -0.04 & 0.04 & 0.05 & 0.04 & -0.02 & $0.00-$ & -0.03 & 1.00 \\
\hline & $M$ & 0.25 & 10.84 & 2.56 & 0.14 & 3.29 & 0.17 & 4.29 & 3.83 & 0.981 & 10.58 & 0.26 & 0.58 & 0.35 & 0.36 & 0.40 & 0.25 & $0.17 \theta$ & 61.52 & 2.17 & 2.77 & 0.07 & 0.13 & 0.23 & 8.77 \\
\hline & SD & 0.11 & 3.82 & 0.77 & 0.35 & 1.50 & 0.37 & 0.66 & 1.00 & 1.88 & 9.87 & 0.70 & 0.49 & 0.48 & 0.48 & 0.49 & 0.41 & 0.383 & 33.19 & 6.94 & 0.63 & 0.25 & 0.34 & 0.42 & 4.22 \\
\hline
\end{tabular}

Note: Statistically significant correlations at the 5 percent level $(p<0.05)$ are marked bold: two-tail tests. 
Table 2. Selectivity of entrepreneurial judgment

\begin{tabular}{|c|c|c|c|c|c|c|c|}
\hline \multirow{2}{*}{$\begin{array}{l}\text { Variables } \\
\text { Time Spent (log) }\end{array}$} & \multirow[t]{2}{*}{ Control } & \multicolumn{2}{|c|}{ Experience } & \multicolumn{2}{|c|}{ Uncertainty } & \multicolumn{2}{|c|}{ Cognition } \\
\hline & & $\begin{array}{l}0.0163 * * * \\
(0.0062)\end{array}$ & & & & & \\
\hline Formal Business Plan & & & $\begin{array}{l}0.0317^{* * * *} \\
(0.0132)\end{array}$ & & & & \\
\hline Task Uncertainty & & & & $\begin{array}{l}-0.0036 \\
(0.0030)\end{array}$ & & & \\
\hline Customer Uncertainty & & & & & $\begin{array}{l}0.0097 \\
(0.0123)\end{array}$ & & \\
\hline Self-Efficacy & & & & & & $\begin{array}{l}-0.0037 \\
(0.0069)\end{array}$ & \\
\hline Decisiveness & & & & & & & $\begin{array}{l}0.0099 * * \\
(0.0046)\end{array}$ \\
\hline Founding Experience & $\begin{array}{l}0.0040 \\
(0.0032)\end{array}$ & $\begin{array}{l}0.0040 \\
(0.0032)\end{array}$ & $\begin{array}{l}0.0039 \\
(0.0032)\end{array}$ & $\begin{array}{l}0.0041 \\
(0.0032)\end{array}$ & $\begin{array}{l}0.0040 \\
(0.0032)\end{array}$ & $\begin{array}{l}0.0040 \\
(0.0032)\end{array}$ & $\begin{array}{l}0.0043 \\
(0.0032)\end{array}$ \\
\hline Managerial Experience & $\begin{array}{l}0.0004 \\
(0.0005)\end{array}$ & $\begin{array}{l}0.0003 \\
(0.0005)\end{array}$ & $\begin{array}{l}0.0005 \\
(0.0005)\end{array}$ & $\begin{array}{l}0.0004 \\
(0.0005)\end{array}$ & $\begin{array}{l}0.0005 \\
(0.0005)\end{array}$ & $\begin{array}{l}0.0004 \\
(0.0005)\end{array}$ & $\begin{array}{l}0.0003 \\
(0.0005)\end{array}$ \\
\hline Business Portfolio & $\begin{array}{l}-0.0043 \\
(0.0084)\end{array}$ & $\begin{array}{l}-0.0040 \\
(0.0084)\end{array}$ & $\begin{array}{l}-0.0032 \\
(0.0084)\end{array}$ & $\begin{array}{l}-0.0045 \\
(0.0084)\end{array}$ & $\begin{array}{l}-0.0044 \\
(0.0084)\end{array}$ & $\begin{array}{l}-0.0045 \\
(0.0085)\end{array}$ & $\begin{array}{l}-0.0050 \\
(0.0084)\end{array}$ \\
\hline Employed Full-time & $\begin{array}{l}0.0075 \\
(0.0095)\end{array}$ & $\begin{array}{l}0.0059 \\
(0.0095)\end{array}$ & $\begin{array}{l}0.0066 \\
(0.0095)\end{array}$ & $\begin{array}{l}0.0072 \\
(0.0095)\end{array}$ & $\begin{array}{l}0.0080 \\
(0.0095)\end{array}$ & $\begin{array}{l}0.0079 \\
(0.0095)\end{array}$ & $\begin{array}{l}0.0073 \\
(0.0095)\end{array}$ \\
\hline College Education & $\begin{array}{l}0.0287^{* * * *} \\
(0.0098)\end{array}$ & $\begin{array}{l}0.0277^{* * *} \\
(0.0097)\end{array}$ & $\begin{array}{l}0.0250 * * \\
(0.0098)\end{array}$ & $\begin{array}{l}0.0277^{* * *} \\
(0.0098)\end{array}$ & $\begin{array}{l}0.0285^{* * *} \\
(0.0098)\end{array}$ & $\begin{array}{l}0.0281^{* * * *} \\
(0.0098)\end{array}$ & $\begin{array}{l}0.0267 * * * \\
(0.0098)\end{array}$ \\
\hline Married & $\begin{array}{l}0.0015 \\
(0.0095)\end{array}$ & $\begin{array}{l}0.0032 \\
(0.0095)\end{array}$ & $\begin{array}{l}0.0011 \\
(0.0094)\end{array}$ & $\begin{array}{l}0.0004 \\
(0.0095)\end{array}$ & $\begin{array}{l}0.0015 \\
(0.0095)\end{array}$ & $\begin{array}{l}0.0015 \\
(0.0095)\end{array}$ & $\begin{array}{l}0.0001 \\
(0.0095)\end{array}$ \\
\hline Female & $\begin{array}{l}-0.0146 \\
(0.0095)\end{array}$ & $\begin{array}{l}-0.0138 \\
(0.0095)\end{array}$ & $\begin{array}{l}-0.0145 \\
(0.0095)\end{array}$ & $\begin{array}{l}-0.0136 \\
(0.0096)\end{array}$ & $\begin{array}{l}-0.0142 \\
(0.0096)\end{array}$ & $\begin{array}{l}-0.0148 \\
(0.0096)\end{array}$ & $\begin{array}{l}-0.0143 \\
(0.0095)\end{array}$ \\
\hline Opportunity Expectancy (log) & $\begin{array}{l}-0.0084 \\
(0.0119)\end{array}$ & $\begin{array}{l}-0.0110 \\
(0.0119)\end{array}$ & $\begin{array}{l}-0.0104 \\
(0.0119)\end{array}$ & $\begin{array}{l}-0.0083 \\
(0.0119)\end{array}$ & $\begin{array}{l}-0.0082 \\
(0.0119)\end{array}$ & $\begin{array}{l}-0.0087 \\
(0.0119)\end{array}$ & $\begin{array}{l}-0.0081 \\
(0.0119)\end{array}$ \\
\hline Growth Intention & $\begin{array}{l}-0.0283^{* *} \\
(0.0125)\end{array}$ & $\begin{array}{l}-0.0273^{* *} \\
(0.0124)\end{array}$ & $\begin{array}{l}-0.0298^{* *} \\
(0.0125)\end{array}$ & $\begin{array}{l}-0.0280 * * \\
(0.0125)\end{array}$ & $\begin{array}{l}-0.0295^{* *} \\
(0.0126)\end{array}$ & $\begin{array}{l}-0.0278 * * \\
(0.0125)\end{array}$ & $\begin{array}{l}-0.0308^{* *} \\
(0.0125)\end{array}$ \\
\hline Local Customers(\%) & $\begin{array}{l}-0.0001 \\
(0.0001)\end{array}$ & $\begin{array}{l}0.0000 \\
(0.0001)\end{array}$ & $\begin{array}{l}-0.0001 \\
(0.0001)\end{array}$ & $\begin{array}{l}-0.0001 \\
(0.0001)\end{array}$ & $\begin{array}{l}-0.0001 \\
(0.0001)\end{array}$ & $\begin{array}{l}-0.0001 \\
(0.0001)\end{array}$ & $\begin{array}{l}-0.0001 \\
(0.0001)\end{array}$ \\
\hline International Customers(\%) & $\begin{array}{l}-0.0003 \\
(0.0007)\end{array}$ & $\begin{array}{l}-0.0003 \\
(0.0007)\end{array}$ & $\begin{array}{l}-0.0004 \\
(0.0007)\end{array}$ & $\begin{array}{l}-0.0003 \\
(0.0007)\end{array}$ & $\begin{array}{l}-0.0003 \\
(0.0007)\end{array}$ & $\begin{array}{l}-0.0003 \\
(0.0007)\end{array}$ & $\begin{array}{l}-0.0002 \\
(0.0007)\end{array}$ \\
\hline Founding Environment & $\begin{array}{l}0.0181^{* *} \\
(0.0073)\end{array}$ & $\begin{array}{l}0.0171 * * \\
(0.0073)\end{array}$ & $\begin{array}{l}0.0177^{* *} \\
(0.0073)\end{array}$ & $\begin{array}{l}0.0186 * * \\
(0.0073)\end{array}$ & $\begin{array}{l}0.0180 * * \\
(0.0073)\end{array}$ & $\begin{array}{l}0.0177^{* *} \\
(0.0074)\end{array}$ & $\begin{array}{l}0.0184^{* *} \\
(0.0073)\end{array}$ \\
\hline External Funding & $\begin{array}{l}-0.0325^{*} \\
(0.0181)\end{array}$ & $\begin{array}{l}-0.0380 * * \\
(0.0181)\end{array}$ & $\begin{array}{l}-0.0366^{* *} \\
(0.0181)\end{array}$ & $\begin{array}{l}-0.0323^{*} \\
(0.0181)\end{array}$ & $\begin{array}{l}-0.0322^{*} \\
(0.0181)\end{array}$ & $\begin{array}{l}-0.0321^{*} \\
(0.0181)\end{array}$ & $\begin{array}{l}-0.0335^{*} \\
(0.0180)\end{array}$ \\
\hline Development Phase & $\begin{array}{l}0.0237^{*} \\
(0.0135)\end{array}$ & $\begin{array}{l}0.0136 \\
(0.0140)\end{array}$ & $\begin{array}{l}0.0242^{*} \\
(0.0135)\end{array}$ & $\begin{array}{l}0.0222 \\
(0.0136)\end{array}$ & $\begin{array}{l}0.0242^{*} \\
(0.0135)\end{array}$ & $\begin{array}{l}0.0230^{*} \\
(0.0136)\end{array}$ & $\begin{array}{l}0.0245^{*} \\
(0.0135)\end{array}$ \\
\hline R\&D Intensity & $\begin{array}{l}-0.0288^{* * *} \\
(0.0110)\end{array}$ & $\begin{array}{l}-0.0310^{* * *} \\
(0.0109)\end{array}$ & $\begin{array}{l}-0.0287^{* * *} \\
(0.0109)\end{array}$ & $\begin{array}{l}-0.0295^{* * *} \\
(0.0110)\end{array}$ & $\begin{array}{l}-0.0295^{* * *} \\
(0.0110)\end{array}$ & $\begin{array}{l}-0.0283^{* * *} \\
(0.0110)\end{array}$ & $\begin{array}{l}-0.0272^{* *} \\
(0.0109)\end{array}$ \\
\hline Industry SIC & $\begin{array}{l}0.0004 \\
(0.0011)\end{array}$ & $\begin{array}{l}0.0003 \\
(0.0011)\end{array}$ & $\begin{array}{l}0.0002 \\
(0.0011)\end{array}$ & $\begin{array}{l}0.0004 \\
(0.0011)\end{array}$ & $\begin{array}{l}0.0004 \\
(0.0011)\end{array}$ & $\begin{array}{l}0.0004 \\
(0.0011)\end{array}$ & $\begin{array}{l}0.0003 \\
(0.0011)\end{array}$ \\
\hline Constant & $\begin{array}{l}0.1934 * * * \\
(0.0277)\end{array}$ & $\begin{array}{l}0.1570 * * * \\
(0.0308)\end{array}$ & $\begin{array}{l}0.1941 * * * \\
(0.0275)\end{array}$ & $\begin{array}{l}0.2050 * * * \\
(0.0294)\end{array}$ & $\begin{array}{l}0.1909 * * * \\
(0.0279)\end{array}$ & $\begin{array}{l}0.2009 * * * \\
(0.0426)\end{array}$ & $\begin{array}{l}0.1567 * * * \\
(0.0324)\end{array}$ \\
\hline $\mathrm{N}$ & 524 & 524 & 524 & 524 & 524 & 524 & 524 \\
\hline $\mathrm{F}$ & 3.09 & 3.35 & 3.28 & 2.99 & 2.95 & 2.92 & 3.20 \\
\hline Probability $>$ F & 0.00 & 0.00 & 0.00 & 0.00 & 0.00 & 0.00 & 0.00 \\
\hline $\mathrm{R} 2$ & 0.09 & 0.10 & 0.10 & 0.09 & 0.09 & 0.09 & 0.10 \\
\hline
\end{tabular}

Note: Positive coefficients indicate greater selectivity of venture-specific knowledge by the entrepreneur in the new venture.

${ }^{*} p<0.1,{ }^{* *} p<0.05, * * * p<0.01$. 
Table 2. Selectivity of entrepreneurial judgment (continued)

\begin{tabular}{|c|c|c|c|c|c|c|c|}
\hline Variables & H12a & H34a & H56a & H1234a & H1256a & H3456a & H123456a \\
\hline Time Spent (log) & $\begin{array}{l}0.0146^{* * *} \\
(0.0062)\end{array}$ & & & $\begin{array}{l}0.0142^{* *} \\
(0.0062)\end{array}$ & $\begin{array}{l}0.0151 * * * \\
(0.0062)\end{array}$ & & $\begin{array}{l}0.0147 * * * \\
(0.0062)\end{array}$ \\
\hline Formal Business Plan & $\begin{array}{l}0.0276 * * \\
(0.0133)\end{array}$ & & & $\begin{array}{l}0.0268 * * \\
(0.0133)\end{array}$ & $\begin{array}{l}0.0248 * * \\
(0.0134)\end{array}$ & & $\begin{array}{l}0.0239 * * \\
(0.0135)\end{array}$ \\
\hline Task Uncertainty & & $\begin{array}{l}-0.0039 \\
(0.0031)\end{array}$ & & $\begin{array}{l}-0.0033 \\
(0.0030)\end{array}$ & & $\begin{array}{l}-0.0040 \\
(0.0031)\end{array}$ & $\begin{array}{l}-0.0036 \\
(0.0031)\end{array}$ \\
\hline Customer Uncertainty & & $\begin{array}{l}0.0115 \\
(0.0124)\end{array}$ & & $\begin{array}{l}0.0090 \\
(0.0123)\end{array}$ & & $\begin{array}{l}0.0140 \\
(0.0124)\end{array}$ & $\begin{array}{l}0.0115 \\
(0.0124)\end{array}$ \\
\hline Self-Efficacy & & & $\begin{array}{l}-0.0047 \\
(0.0069)\end{array}$ & & & $\begin{array}{l}-0.0 \\
0.0\end{array}$ & $\begin{array}{l}-0.0084 \\
(0.0070)\end{array}$ \\
\hline Decisiveness & & & $\begin{array}{l}0.0101^{* *} \\
(0.0046)\end{array}$ & & $\begin{array}{l}0.0086^{* *} \\
(0.0046)\end{array}$ & $\begin{array}{l}0.0103^{* *} \\
(0.0047)\end{array}$ & $\begin{array}{l}0.0088^{* *} \\
(0.0047)\end{array}$ \\
\hline Founding Experience & $\begin{array}{l}0.0039 \\
(0.0032)\end{array}$ & $\begin{array}{l}0.0040 \\
(0.0032)\end{array}$ & $\begin{array}{l}0.0042 \\
(0.0032)\end{array}$ & & & & $\begin{array}{l}0.0040 \\
(0.0032)\end{array}$ \\
\hline Managerial Experience & $\begin{array}{l}0.0004 \\
(0.0005)\end{array}$ & $\begin{array}{l}0.00 \\
(0.0\end{array}$ & $\begin{array}{l}0.0 \\
10.0\end{array}$ & $\begin{array}{l}0.0004 \\
(0.0005)\end{array}$ & $\begin{array}{l}0.0 \\
10.0\end{array}$ & & $\begin{array}{l}3 \\
05)\end{array}$ \\
\hline Busin & $\begin{array}{l}-0.0 \\
(0.0\end{array}$ & & $\begin{array}{l}-0.0 \\
(0.0\end{array}$ & & & & $\begin{array}{l}49 \\
84)\end{array}$ \\
\hline Employed Full-time & & & & & & & \\
\hline Colle & $\begin{array}{l}0.024 \\
0.00\end{array}$ & $\begin{array}{l}* * * \\
3)\end{array}$ & $\begin{array}{l}0.02 \\
0.00\end{array}$ & $\begin{array}{l}0.02 \\
10.00\end{array}$ & & $\begin{array}{l}0.0 \\
0.1\end{array}$ & $\begin{array}{l}0.0207^{* *} \\
(0.0099)\end{array}$ \\
\hline Married & $\begin{array}{l}0.0027 \\
(0.0094)\end{array}$ & & & & & & $\begin{array}{l}0.0003 \\
(0.0095)\end{array}$ \\
\hline Female & $\begin{array}{l}-0.01 \\
(0.00\end{array}$ & & & & & & \\
\hline Opportunity Expectancy (log) & $\begin{array}{l}-0.0124 \\
(0.0118)\end{array}$ & $\begin{array}{l}-0.0 \\
10.0\end{array}$ & $\begin{array}{l}-0.0 \\
(0.0\end{array}$ & $\begin{array}{l}-0.0 \\
10.0\end{array}$ & $\begin{array}{l}-0 . \\
0 .\end{array}$ & $\begin{array}{l}-0.0 \\
0.0\end{array}$ & $\begin{array}{l}-0.0121 \\
(0.0118)\end{array}$ \\
\hline Growth Intention & $\begin{array}{l}-0.0288^{* *} \\
(0.0124)\end{array}$ & $\begin{array}{l}-0.0294^{* *} \\
(0.0126)\end{array}$ & $\begin{array}{l}-0.0303^{* *} \\
(0.0125)\end{array}$ & $\begin{array}{l}-0.0296^{* *} \\
(0.0125)\end{array}$ & $\begin{array}{l}-0.0300^{* *} \\
(0.0125)\end{array}$ & $\begin{array}{l}-0.0316^{* *} \\
(0.0126)\end{array}$ & $\begin{array}{l}-0.0310 * * \\
(0.0126)\end{array}$ \\
\hline Locé & $\begin{array}{l}-0.0001 \\
(0.0001)\end{array}$ & $\begin{array}{l}-0.0 \\
10.0\end{array}$ & $\begin{array}{l}-0.0 \\
(0.0\end{array}$ & $\begin{array}{l}0.00 \\
(0.0\end{array}$ & $\begin{array}{l}0.00 \\
(0.0\end{array}$ & $\begin{array}{l}-0.0 \\
(0.0\end{array}$ & $\begin{array}{l}0.0000 \\
(0.0001)\end{array}$ \\
\hline International Customers(\%) & $\begin{array}{l}-0.0003 \\
(0.0007)\end{array}$ & & $\begin{array}{l}-0.0002 \\
(0.0007)\end{array}$ & & & $\begin{array}{l}-0.0002 \\
(0.0007)\end{array}$ & $\begin{array}{l}-0.0003 \\
(0.0007)\end{array}$ \\
\hline Founc & $\begin{array}{l}0.0168^{* *} \\
(0.0073)\end{array}$ & $\begin{array}{l}0.0184^{* *} \\
(0.0073)\end{array}$ & $\begin{array}{l}0.0178 * * \\
(0.0074)\end{array}$ & $\begin{array}{l}0.0172^{* *} \\
(0.0073)\end{array}$ & $\begin{array}{l}0.0162^{* *} \\
(0.0073)\end{array}$ & $\begin{array}{l}0.0180 * * \\
(0.0074)\end{array}$ & $\begin{array}{l}0.0164 * * \\
(0.0073)\end{array}$ \\
\hline External Funding & $\begin{array}{l}-0.0410^{* *} \\
(0.0181)\end{array}$ & $\begin{array}{l}-0.03 \\
(0.01\end{array}$ & $\begin{array}{l}-0.03 \\
(0.01\end{array}$ & $\begin{array}{l}-0.0402^{* *} \\
(0.0181)\end{array}$ & $\begin{array}{l}-0.0410^{* *} \\
(0.0181)\end{array}$ & $\begin{array}{l}-0.0322^{*} \\
(0.0180)\end{array}$ & $\begin{array}{l}-0.0400 * * \\
(0.0181)\end{array}$ \\
\hline Dev & $\begin{array}{l}0.0150 \\
(0.0140)\end{array}$ & $\begin{array}{l}0.0226^{*} \\
(0.0136)\end{array}$ & $\begin{array}{l}0.0236^{*} \\
(0.0136)\end{array}$ & $\begin{array}{l}0.0143 \\
(0.0140)\end{array}$ & $\begin{array}{l}0.0139 \\
(0.0140)\end{array}$ & $\begin{array}{l}0.0223 \\
(0.0136)\end{array}$ & $\begin{array}{l}0.0129 \\
(0.0141)\end{array}$ \\
\hline R\&D Intensity & $\begin{array}{l}-0.0307^{* * *} \\
(0.0109)\end{array}$ & $\begin{array}{l}-0.0304 * * * \\
(0.0110)\end{array}$ & $\begin{array}{l}-0.0265^{* * *} \\
(0.0110)\end{array}$ & $\begin{array}{l}-0.0319 * * * \\
(0.0109)\end{array}$ & $\begin{array}{l}-0.0284^{* *} \\
(0.0109)\end{array}$ & $\begin{array}{l}-0.0281^{* *} \\
(0.0110)\end{array}$ & $\begin{array}{l}-0.0297^{* * *} \\
(0.0110)\end{array}$ \\
\hline Industry SIC & $\begin{array}{l}0.0002 \\
(0.0011)\end{array}$ & $\begin{array}{l}0.0004 \\
(0.0011)\end{array}$ & $\begin{array}{l}0.0003 \\
(0.0011)\end{array}$ & $\begin{array}{l}0.0002 \\
(0.0011)\end{array}$ & $\begin{array}{l}0.0002 \\
(0.0011)\end{array}$ & $\begin{array}{l}0.0004 \\
(0.0011)\end{array}$ & $\begin{array}{l}0.0002 \\
(0.0011)\end{array}$ \\
\hline Constant & $\begin{array}{l}0.1613^{* * *} \\
(0.0307)\end{array}$ & $\begin{array}{l}0.2030 * * * \\
(0.0295)\end{array}$ & $\begin{array}{l}0.1777^{* * *} \\
(0.0451)\end{array}$ & $\begin{array}{l}0.1706^{* * *} \\
(0.0326)\end{array}$ & $\begin{array}{l}0.1614^{* * * *} \\
(0.0464)\end{array}$ & $\begin{array}{l}0.1931^{* * * *} \\
(0.0478)\end{array}$ & $\begin{array}{l}0.1761 * * * \\
(0.0492)\end{array}$ \\
\hline $\mathrm{N}$ & & & & & & & \\
\hline $\mathrm{F}$ & 3.4 & 2.8 & $3 .($ & 3.1 & 3.3 & 2.8 & 3.1 \\
\hline & 0.0 & 0.0 & 0.0 & 0.00 & 0.0 & 0.00 & 0.00 \\
\hline $\mathrm{R} 2$ & 0.11 & 0.09 & 0.10 & 0.11 & 0.12 & 0.10 & 0.12 \\
\hline
\end{tabular}

Note: Positive coefficients indicate greater selectivity of venture-specific knowledge by the entrepreneur in the new venture.

${ }^{*} p<0.1, * * p<0.05, * * * p<0.01$. 
Table 3. Conviction in entrepreneurial judgment

\begin{tabular}{|c|c|c|c|c|c|c|c|}
\hline \multirow{2}{*}{$\begin{array}{l}\text { Variables } \\
\text { Time Spent (log) }\end{array}$} & \multirow{2}{*}{ Control } & \multicolumn{2}{|c|}{ Experience } & \multicolumn{2}{|c|}{ Uncertainty } & \multicolumn{2}{|c|}{ Cognition } \\
\hline & & $\begin{array}{l}0.4326^{* *} \\
(0.2222)\end{array}$ & & & & & \\
\hline Formal Business Plan & & & $\begin{array}{l}0.6614 * \\
(0.4759)\end{array}$ & & & & \\
\hline Task Uncertainty & & & & $\begin{array}{l}0.0550 \\
(0.1092)\end{array}$ & & & \\
\hline Customer Uncertainty & & & & & $\begin{array}{l}1.8185^{* * *} \\
(0.4360)\end{array}$ & & \\
\hline Self-Efficacy & & & & & & $\begin{array}{l}0.8974 * * * \\
(0.2461)\end{array}$ & \\
\hline Decisiveness & & & & & & & $\begin{array}{l}0.4644 * * * \\
(0.1653)\end{array}$ \\
\hline Founding Experience & $\begin{array}{l}0.1172 \\
(0.1148)\end{array}$ & $\begin{array}{l}0.1164 \\
(0.1144)\end{array}$ & $\begin{array}{l}0.1140 \\
(0.1147)\end{array}$ & $\begin{array}{l}0.1165 \\
(0.1148)\end{array}$ & $\begin{array}{l}0.1063 \\
(0.1130)\end{array}$ & $\begin{array}{l}0.1257 \\
(0.1134)\end{array}$ & $\begin{array}{l}0.1277 \\
(0.1140)\end{array}$ \\
\hline Managerial Experience & $\begin{array}{l}0.0018 \\
(0.0175)\end{array}$ & $\begin{array}{l}-0.0008 \\
(0.0175)\end{array}$ & $\begin{array}{l}0.0028 \\
(0.0175)\end{array}$ & $\begin{array}{l}0.0022 \\
(0.0176)\end{array}$ & $\begin{array}{l}0.0085 \\
(0.0173)\end{array}$ & $\begin{array}{l}-0.0013 \\
(0.0173)\end{array}$ & $\begin{array}{l}-0.0063 \\
(0.0176)\end{array}$ \\
\hline Business Portfolio & $\begin{array}{l}-0.5482 * \\
(0.3030)\end{array}$ & $\begin{array}{l}-0.5414^{*} \\
(0.3022)\end{array}$ & $\begin{array}{l}-0.5268^{*} \\
(0.3031)\end{array}$ & $\begin{array}{l}-0.5439 * \\
(0.3033)\end{array}$ & $\begin{array}{l}-0.5739^{*} \\
(0.2983)\end{array}$ & $\begin{array}{l}-0.4943^{*} \\
(0.2997)\end{array}$ & $\begin{array}{l}-0.5838^{*} \\
(0.3012)\end{array}$ \\
\hline Employed Full-time & $\begin{array}{l}0.5124 \\
(0.3410)\end{array}$ & $\begin{array}{l}0.4689 \\
(0.3408)\end{array}$ & $\begin{array}{l}0.4944 \\
(0.3409)\end{array}$ & $\begin{array}{l}0.5167 \\
(0.3414)\end{array}$ & $\begin{array}{l}0.5963^{*} \\
(0.3362)\end{array}$ & $\begin{array}{l}0.4147 \\
(0.3380)\end{array}$ & $\begin{array}{l}0.5009 \\
(0.3387)\end{array}$ \\
\hline College Education & $\begin{array}{l}0.0644 \\
(0.3499)\end{array}$ & $\begin{array}{l}0.0389 \\
(0.3492)\end{array}$ & $\begin{array}{l}-0.0132 \\
(0.3540)\end{array}$ & $\begin{array}{l}0.0795 \\
(0.3515)\end{array}$ & $\begin{array}{l}0.0281 \\
(0.3445)\end{array}$ & $\begin{array}{l}0.2114 \\
(0.3481)\end{array}$ & $\begin{array}{l}-0.0270 \\
(0.3491)\end{array}$ \\
\hline Married & $\begin{array}{l}-0.4736 \\
(0.3407)\end{array}$ & $\begin{array}{l}-0.4286 \\
(0.3405)\end{array}$ & $\begin{array}{l}-0.4827 \\
(0.3404)\end{array}$ & $\begin{array}{l}-0.4567 \\
(0.3426)\end{array}$ & $\begin{array}{l}-0.4790 \\
(0.3353)\end{array}$ & $\begin{array}{l}-0.4677 \\
(0.3366)\end{array}$ & $\begin{array}{l}-0.5379 \\
(0.3391)\end{array}$ \\
\hline Female & $\begin{array}{l}0.2288 \\
(0.3427)\end{array}$ & $\begin{array}{l}0.2507 \\
(0.3420)\end{array}$ & $\begin{array}{l}0.2324 \\
(0.3424)\end{array}$ & $\begin{array}{l}0.2133 \\
(0.3443)\end{array}$ & $\begin{array}{l}0.3140 \\
(0.3379)\end{array}$ & $\begin{array}{l}0.2650 \\
(0.3389)\end{array}$ & $\begin{array}{l}0.2426 \\
(0.3404)\end{array}$ \\
\hline Opportunity Expectancy (log) & $\begin{array}{l}0.4165 \\
(0.4269)\end{array}$ & $\begin{array}{l}0.3475 \\
(0.4272)\end{array}$ & $\begin{array}{l}0.3766 \\
(0.4274)\end{array}$ & $\begin{array}{l}0.4146 \\
(0.4272)\end{array}$ & $\begin{array}{l}0.4619 \\
(0.4203)\end{array}$ & $\begin{array}{l}0.4803 \\
(0.4221)\end{array}$ & $\begin{array}{l}0.4312 \\
(0.4240)\end{array}$ \\
\hline Growth Intention & $\begin{array}{l}1.6458^{* * *} \\
(0.4486)\end{array}$ & $\begin{array}{l}1.6714^{* * * *} \\
(0.4476)\end{array}$ & $\begin{array}{l}1.6134^{* * *} \\
(0.4488)\end{array}$ & $\begin{array}{l}1.6410 * * * \\
(0.4490)\end{array}$ & $\begin{array}{l}1.4159 * * * \\
(0.4450)\end{array}$ & $\begin{array}{l}1.5432^{* * *} \\
(0.4442)\end{array}$ & $\begin{array}{l}1.5278 * * * \\
(0.4476)\end{array}$ \\
\hline Local Customers(\%) & $\begin{array}{l}-0.0028 \\
(0.0053)\end{array}$ & $\begin{array}{l}-0.0019 \\
(0.0053)\end{array}$ & $\begin{array}{l}-0.0028 \\
(0.0053)\end{array}$ & $\begin{array}{l}-0.0027 \\
(0.0053)\end{array}$ & $\begin{array}{l}-0.0012 \\
(0.0052)\end{array}$ & $\begin{array}{l}-0.0021 \\
(0.0052)\end{array}$ & $\begin{array}{l}-0.0020 \\
(0.0053)\end{array}$ \\
\hline International Customers(\%) & $\begin{array}{l}-0.0077 \\
(0.0255)\end{array}$ & $\begin{array}{l}-0.0071 \\
(0.0255)\end{array}$ & $\begin{array}{l}-0.0093 \\
(0.0255)\end{array}$ & $\begin{array}{l}-0.0079 \\
(0.0255)\end{array}$ & $\begin{array}{l}-0.0118 \\
(0.0251)\end{array}$ & $\begin{array}{l}-0.0039 \\
(0.0252)\end{array}$ & $\begin{array}{l}-0.0037 \\
(0.0254)\end{array}$ \\
\hline Founding Environment & $\begin{array}{l}-1.0741^{* * *} \\
(0.2634)\end{array}$ & $\begin{array}{l}-1.1012^{* * *} \\
(0.2630)\end{array}$ & $\begin{array}{l}-1.0829 * * * \\
(0.2632)\end{array}$ & $\begin{array}{l}-1.0813^{* * *} \\
(0.2640)\end{array}$ & $\begin{array}{l}-1.1016^{* * *} \\
(0.2593)\end{array}$ & $\begin{array}{l}-0.9644^{* * *} \\
(0.2620)\end{array}$ & $\begin{array}{l}-1.0612^{* * *} \\
(0.2617)\end{array}$ \\
\hline External Funding & $\begin{array}{l}-0.8948 \\
(0.6487)\end{array}$ & $\begin{array}{l}-1.0406 \\
(0.6513)\end{array}$ & $\begin{array}{l}-0.9808 \\
(0.6511)\end{array}$ & $\begin{array}{l}-0.8981 \\
(0.6492)\end{array}$ & $\begin{array}{l}-0.8282 \\
(0.6387)\end{array}$ & $\begin{array}{l}-0.9894 \\
(0.6415)\end{array}$ & $\begin{array}{l}-0.9416 \\
(0.6446)\end{array}$ \\
\hline Development Phase & $\begin{array}{l}-0.0444 \\
(0.4851)\end{array}$ & $\begin{array}{l}-0.3150 \\
(0.5034)\end{array}$ & $\begin{array}{l}-0.0353 \\
(0.4847)\end{array}$ & $\begin{array}{l}-0.0208 \\
(0.4877)\end{array}$ & $\begin{array}{l}0.0467 \\
(0.4780)\end{array}$ & $\begin{array}{l}0.1355 \\
(0.4819)\end{array}$ & $\begin{array}{l}-0.0072 \\
(0.4821)\end{array}$ \\
\hline R\&D Intensity & $\begin{array}{l}1.2352^{* * *} \\
(0.3931)\end{array}$ & $\begin{array}{l}1.1772 * * * \\
(0.3932)\end{array}$ & $\begin{array}{l}1.2364 * * * \\
(0.3928)\end{array}$ & $\begin{array}{l}1.2456 * * * \\
(0.3940)\end{array}$ & $\begin{array}{l}1.1021 * * * \\
(0.3882)\end{array}$ & $\begin{array}{l}1.1155^{* * *} \\
(0.3898)\end{array}$ & $\begin{array}{l}1.3100 * * * \\
(0.3914)\end{array}$ \\
\hline Industry SIC & $\begin{array}{l}0.0428 \\
(0.0386)\end{array}$ & $\begin{array}{l}0.0410 \\
(0.0385)\end{array}$ & $\begin{array}{l}0.0392 \\
(0.0386)\end{array}$ & $\begin{array}{l}0.0425 \\
(0.0386)\end{array}$ & $\begin{array}{l}0.0519 \\
(0.0380)\end{array}$ & $\begin{array}{l}0.0405 \\
(0.0381)\end{array}$ & $\begin{array}{l}0.0415 \\
(0.0383)\end{array}$ \\
\hline Constant & $\begin{array}{l}12.7938^{* * *} \\
(0.9924)\end{array}$ & $\begin{array}{l}11.8242^{* * *} \\
(1.1079)\end{array}$ & $\begin{array}{l}12.8070^{* * * *} \\
(0.9915)\end{array}$ & $\begin{array}{l}12.6141 * * * \\
(1.0553)\end{array}$ & $\begin{array}{l}12.3163^{* * * *} \\
(0.9834)\end{array}$ & $\begin{array}{l}8.6126^{* * *} \\
(1.5085)\end{array}$ & $\begin{array}{l}11.0721 * * * \\
(1.1607)\end{array}$ \\
\hline $\bar{N}$ & 524 & 524 & 524 & 524 & 524 & 524 & 524 \\
\hline $\mathrm{F}$ & 3.85 & 3.86 & 3.74 & 3.63 & 4.76 & 4.49 & 4.14 \\
\hline Probability > F & 0.00 & 0.00 & 0.00 & 0.00 & 0.00 & 0.00 & 0.00 \\
\hline $\mathrm{R} 2$ & 0.11 & 0.11 & 0.11 & 0.11 & 0.14 & 0.13 & 0.12 \\
\hline
\end{tabular}

Note: Positive coefficients indicate greater conviction in venture-specific knowledge by the entrepreneur in the new venture.

${ }^{*} p<0.1,{ }^{* *} p<0.05, * * * p<0.01$. 
Table 3. Conviction in entrepreneurial judgment (continued)

\begin{tabular}{|c|c|c|c|c|c|c|c|}
\hline Variables & $\mathrm{H} 12 \mathrm{~b}$ & H34b & H56b & H1234b & H1256b & H3456b & H123456b \\
\hline Time Spent (log) & $\begin{array}{l}0.3988 * * \\
(0.2241)\end{array}$ & & & $\begin{array}{l}0.3854 * * \\
(0.2213)\end{array}$ & $\begin{array}{l}0.3366^{*} \\
(0.2214)\end{array}$ & & $\begin{array}{l}0.3273^{*} \\
(0.2177)\end{array}$ \\
\hline Formal Business Plan & $\begin{array}{l}0.5494 \\
(0.4791)\end{array}$ & & & $\begin{array}{l}0.4411 \\
(0.4732)\end{array}$ & $\begin{array}{l}0.2587 \\
(0.4782)\end{array}$ & & $\begin{array}{l}0.1122 \\
(0.4709)\end{array}$ \\
\hline Task Uncertainty & & $\begin{array}{l}0.0051 \\
(0.1081)\end{array}$ & & $\begin{array}{l}0.0189 \\
(0.1081)\end{array}$ & & $\begin{array}{l}0.0813 \\
(0.1073)\end{array}$ & $\begin{array}{l}0.0882 \\
(0.1073)\end{array}$ \\
\hline Customer Uncertainty & & $\begin{array}{l}1.8161^{* * *} \\
(0.4392)\end{array}$ & & $\begin{array}{l}1.7662 * * * \\
(0.4391)\end{array}$ & & $\begin{array}{l}1.8930 * * * \\
(0.4317)\end{array}$ & $\begin{array}{l}1.8654^{* * *} \\
(0.4329)\end{array}$ \\
\hline Self-Efficacy & & & $\begin{array}{l}0.8584^{* * *} \\
(0.2451)\end{array}$ & & $\begin{array}{l}0.8134 * * * \\
(0.2464)\end{array}$ & $\begin{array}{l}0.8748^{* * *} \\
(0.2436)\end{array}$ & $\begin{array}{l}0.8389 * * * \\
(0.2448)\end{array}$ \\
\hline Decisiveness & & & $\begin{array}{l}0.4296^{* * *} \\
(0.1638)\end{array}$ & & $\begin{array}{l}0.4124 * * * \\
(0.1655)\end{array}$ & $\begin{array}{l}0.5002^{* * *} \\
(0.1616)\end{array}$ & $\begin{array}{l}0.4903^{* * * *} \\
(0.1636)\end{array}$ \\
\hline Founding Experience & & & & & & & $\begin{array}{l}0.1228 \\
(0.1108)\end{array}$ \\
\hline Managerial Experience & & & & & & & $\begin{array}{l}40 \\
73)\end{array}$ \\
\hline Business Portfolio & $\begin{array}{l}-0.52 \\
(0.30\end{array}$ & $\begin{array}{l}-0.5 \\
(0.2\end{array}$ & & & & & $\begin{array}{l}-0.5462^{*} \\
(0.2936)\end{array}$ \\
\hline Employed Full-time & & & & & & & \\
\hline Colle & $\begin{array}{l}-0.0 \\
(0.3\end{array}$ & $\begin{array}{l}0.0 \\
(0.3\end{array}$ & $\begin{array}{l}0.1 \\
0 .\end{array}$ & & & & 74) \\
\hline Married & & & & & & & \\
\hline Female & & $\begin{array}{l}0.31 \\
10.3\end{array}$ & & & & & 63) \\
\hline Opportunity Expect & $\begin{array}{l}0.31 \\
0.4\end{array}$ & $\begin{array}{l}0.46 \\
0.4\end{array}$ & $\begin{array}{l}0.4 \\
0.4\end{array}$ & $\begin{array}{l}8 \\
19)\end{array}$ & 18) & 23) & 52 \\
\hline Growth Intention & $\begin{array}{l}1.6425^{* * *} \\
(0.4481)\end{array}$ & $\begin{array}{l}1.4158^{* * *} \\
(0.4454)\end{array}$ & $\begin{array}{l}1.4385^{* * *} \\
(0.4434)\end{array}$ & $\begin{array}{l}1.4221 * * * \\
(0.4451)\end{array}$ & $\begin{array}{l}1.4553^{* * *} \\
(0.4436)\end{array}$ & $\begin{array}{l}1.1722 * * * \\
(0.4393)\end{array}$ & $\begin{array}{l}1.1955^{* * *} \\
(0.4396)\end{array}$ \\
\hline Loc & $\begin{array}{l}-0.0020 \\
(0.0053)\end{array}$ & $\begin{array}{l}-0.00 \\
(0.00\end{array}$ & $\begin{array}{l}-0.0 \\
(0.0\end{array}$ & $\begin{array}{l}-0.0 \\
(0.0\end{array}$ & $\begin{array}{l}-0.0 \\
(0.0\end{array}$ & $\begin{array}{l}0.0 \\
(0.0\end{array}$ & $\begin{array}{l}0.0012 \\
(0.0052)\end{array}$ \\
\hline International Customers(\%) & & $\begin{array}{l}-0.0118 \\
(0.0252)\end{array}$ & & & $\begin{array}{l}-0.0008 \\
(0.0252)\end{array}$ & & $\begin{array}{l}-0.0042 \\
(0.0247)\end{array}$ \\
\hline Founc & $\begin{array}{l}-1.1064^{* * *} \\
(0.2630)\end{array}$ & $\begin{array}{l}-1.1022^{* * *} \\
(0.2599)\end{array}$ & $\begin{array}{l}-0.9572^{* * *} \\
(0.2605)\end{array}$ & $\begin{array}{l}-1.1333^{* * *} \\
(0.2597)\end{array}$ & $\begin{array}{l}-0.9876^{* * *} \\
(0.2609)\end{array}$ & $\begin{array}{l}-0.9924^{* * *} \\
(0.2560)\end{array}$ & $\begin{array}{l}-1.0196^{* * *} \\
(0.2565)\end{array}$ \\
\hline External Funding & $\begin{array}{l}-1.1007^{*} \\
(0.6532)\end{array}$ & $\begin{array}{l}-0.8286 \\
(0.6394)\end{array}$ & $\begin{array}{l}-1.0285 \\
(0.6380)\end{array}$ & $\begin{array}{l}-1.0185 \\
(0.6444)\end{array}$ & $\begin{array}{l}-1.1 \\
0.6\end{array}$ & $\begin{array}{l}-0.9730 \\
(0.6268)\end{array}$ & $\begin{array}{l}-1.0946^{*} \\
(0.6324)\end{array}$ \\
\hline Dev & $\begin{array}{l}-0.2863 \\
(0.5038)\end{array}$ & $\begin{array}{l}0.0488 \\
(0.4805)\end{array}$ & $\begin{array}{l}0.1620 \\
(0.4792)\end{array}$ & $\begin{array}{l}-0.1828 \\
(0.4987)\end{array}$ & $\begin{array}{l}-0.0553 \\
(0.4998)\end{array}$ & $\begin{array}{l}0.3006 \\
(0.4739)\end{array}$ & $\begin{array}{l}0.0910 \\
(0.4938)\end{array}$ \\
\hline R\&D Intensity & $\begin{array}{l}1.1827^{* * *} \\
(0.3931)\end{array}$ & $\begin{array}{l}1.1032^{* * *} \\
(0.3894)\end{array}$ & $\begin{array}{l}1.1898 * * * \\
(0.3886)\end{array}$ & $\begin{array}{l}1.0586 * * * \\
(0.3895)\end{array}$ & $\begin{array}{l}1.1484^{* * *} \\
(0.3892)\end{array}$ & $\begin{array}{l}1.0758^{* * *} \\
(0.3832)\end{array}$ & $\begin{array}{l}1.0386 * * * \\
(0.3838)\end{array}$ \\
\hline Industry SIC & $\begin{array}{l}0.0382 \\
(0.0385)\end{array}$ & $\begin{array}{l}0.0518 \\
(0.0381)\end{array}$ & $\begin{array}{l}0.0395 \\
(0.0379)\end{array}$ & $\begin{array}{l}0.0476 \\
(0.0381)\end{array}$ & $\begin{array}{l}0.0369 \\
(0.0380)\end{array}$ & $\begin{array}{l}0.0483 \\
(0.0373)\end{array}$ & $\begin{array}{l}0.0464 \\
(0.0374)\end{array}$ \\
\hline Constant & $\begin{array}{l}11.9108^{* * *} \\
(1.1102)\end{array}$ & $\begin{array}{l}12.3001^{* * *} \\
(1.0416)\end{array}$ & $\begin{array}{l}7.2014^{* * *} \\
(1.5935)\end{array}$ & $\begin{array}{l}11.4133^{* * *} \\
(1.1588)\end{array}$ & $\begin{array}{l}6.7257^{* * *} \\
(1.6526)\end{array}$ & $\begin{array}{l}6.1005^{* * *} \\
(1.6613)\end{array}$ & $\begin{array}{l}5.5576 * * * \\
(1.7215)\end{array}$ \\
\hline $\begin{array}{l}\mathrm{N} \\
\mathrm{F} \\
\text { Prob }\end{array}$ & $\begin{array}{l}524 \\
3.73 \\
0.00\end{array}$ & $\begin{array}{l}524 \\
4.49 \\
0.00\end{array}$ & $\begin{array}{l}524 \\
4.67 \\
0.00\end{array}$ & $\begin{array}{l}524 \\
4.28 \\
0.00\end{array}$ & $\begin{array}{l}524 \\
4.36 \\
0.00\end{array}$ & $\begin{array}{l}524 \\
5.40 \\
0.00\end{array}$ & $\begin{array}{l}524 \\
5.03 \\
0.00\end{array}$ \\
\hline & 0.12 & 0.14 & 0.14 & 0.15 & 0.15 & 0.18 & 0.18 \\
\hline
\end{tabular}

Note: Positive coefficients indicate greater conviction in venture-specific knowledge by the entrepreneur in the new venture.

${ }^{*} p<0.1, * * p<0.05, * * * p<0.01$. 